\title{
Re-Expressing Parenthood
}

\author{
Katharine T. Bartlett $†$
}

\section{INTRODUCTION}

Legal scholarship in recent years has emphasized the law's indirect effects on our modes of expression, our perceptions of ourselves, and our relationships with others. ${ }^{1}$ This scholarship understands law not only as a style of problem-solving leading to rules that define minimally acceptable behavior, ${ }^{2}$ but also as a system that produces and reproduces the dispositions and values of its citizens. ${ }^{3}$ That law influences the character as well as the behavior of its citizens seems intuitively obvious. Turning that in-

† Professor of Law, Duke University School of Law. An early version of this paper was presented at the July 1987 Feminism and Legal Theory Conference on Women and Intimacy, convened by Martha Fineman at the Institute for Legal Studies, University of Wisconsin Law School. In addition to the helpful criticisms and encouragements I received from participants at that Conference, I benefitted from the thoughtful suggestions of Herma Hill Kay, Martha Minow, and Deborah Rhode, from the able and enthusiastic research assistance of Margaret Force, Barbara Heggie, Amy Kincaid, and Janelle Sherlock, and from the firm and responsible editorial hand of Kim Treiger. Most of all, I gained from the intellectual and emotional support of Chris Schroeder, whose commitment to relationship over rights helps me to sustain mine.

1. See, e.g., G. Geertz, Local KNowledge: Further Essays In InTERPRETIVe ANTHRopolOGY 173 (1983) (law as "distinctive manner of imagining the real"); M. GLENDON, ABORTION AND DIVORCE IN WESTERN LAW 8 (1987) (law "tells stories about the culture that helped to shape it and which it in turn helps to shape"); Fuller, Some Presuppositions Shaping the Concept of "Socialization," in Law, Justice, and the Individual in Society: Psychological and Legal Issues 33, 37 (J. Tapp \& F. Levine eds. 1977) (law stimulates process "whereby a person comes to perceive, respect, and participate in the creation of the reciprocal expectations that arise out of human interaction"); White, Law as Rhetoric, Rhetoric as Law: The Arts of Cultural and Communal Life, 52 U. CHI. L. REv. 684, 684 (1985) (law is rhetoric and "central art by which community and culture are established, maintained, and transformed").

An important segment of this scholarship has stressed how metaphors expressed in the law limit people's imaginations about what is possible. See M. Ball, Lying Down Together: Law, METaPHOR AND THEOLOGY 17, 22, 28, 32-33 (1985); see also Winter, The Metaphor of Standing and the Problem of Governance, 40 STAN. L. REv. 1371 (1988) (metaphor of standing has influenced how legal doctrine has developed). For a coherent, documented presentation of the role of metaphor in influencing our perceptions, see G. LAkoff \& M. Johnson, Metaphors We Live By (1980).

2. The traditional view that law exists to define minimally acceptable behavior is captured best, perhaps, by Holmes" "bad man" theory of the law: "If you want to know the law and nothing else, you must look at it as a bad man, who cares only for the material consequences which such knowledge enables him to predict, not as a good one, who finds his reasons for conduct, whether inside the law or outside of it, in the vaguer sanctions of conscience." O.W. HoLMES, The Path of the Law, in Col.LeCTEd LeGal Papers 171 (1920).

3. The study of how the legal system produces and reproduces itself has been labelled autopoiesis. For a collection of essays on law as an autopoietic system, see AUTOPOIEIIC LAw: A Nrw APPROACH to LAW AND Society (G. Teubner ed. 1988).

4. However intuitive it may now seem, this view challenges the traditional dichotomy between legal and moral constraints that underlies our more established conceptions of law. See, e.g., H.L.A. Hart, The Concept of LAw 165-69 (1961); O.W. Holmes, supra note 2, at 169-79. Even those contemporary scholars advocating a greater emphasis on the public cultivation of virtue typically con- 
sight into constructive recommendations for legal reform, however, is a highly problematic enterprise. ${ }^{5}$

In this article, I argue that the law currently applied to one particular set of child custody disputes expresses a view of parenthood which is undesirable. This view is grounded in notions of exchange and individual rights, and implicity encourages parental possessiveness and selfcenteredness. ${ }^{\circ}$ I suggest how we might proceed to reshape the law to express a better view of parenthood. This alternative view is based upon notions of benevolence and responsibility, and is intended to reinforce parental dispositions toward generosity and other-directedness. I focus on custody disputes in which one biological parent seeks to deny parental status to the other. These include claims by unmarried women seeking "nonmarital motherhood-by-choice," claims by single women seeking to place their newborn children for adoption over the objection of the biological father, and claims by "surrogate" mothers who, after agreeing to bear a child for another, change their minds and seek to retain custody. These cases, which raise fundamental questions about the meaning of parenthood, provide a rich landscape for examining the law's expressive functions. I will be concerned less with the results of any particular law-who wins a dispute-than with the structure and expressive mean-

tinue to see the role of law as confined to charting appropriate behavior, with little or no relevance to defining or producing virtue or character. See, e.g., E. PInCoffs, Quandaries and VIRTUes: AgAinst REDUCTIVISM IN ETHICs 9-10, 18-32 (1986) (law is modelled on quandary ethics rather than virtue ethics).

5. An example of recent legal scholarship that takes account of the expressive effects of law is $\mathbf{M}$. Glendon, supra note 1. Professor Glendon offers numerous recommendations for the reform of laws relating to abortion and divorce in this country based upon her analysis that the "stories" our present laws tell are not as desirable to us as the "stories" told by the laws she proposes (most of which are drawn from her study of Western European law). While I have criticized Glendon both for the content of the reforms she proposes and for her failure to acknowledge the subjectivity of her enterprise, see Bartlett, Storytelling, 1987 DuKE L.J. 760 (1987), her pioneer work represents the constructive potential of this new type of legal scholarship.

Martha Fineman, in her analysis of legal change in child custody decision-making, also has given a great deal of attention to how the language of the law carries us in certain "reform" directions. Fineman, Dominant Discourse, Professional Language, and Legal Change in Child Custody Decisionmaking, 101 HARv. L. Rev. 727 (1988). While Fineman and I disagree about what rhetoric-and what substantive results-are most desirable in child custody law, compare id. at 760-61, 768-74 (arguing for primary parent rule in child custody cases and stressing notions of fairness to mothers), with Bartlett \& Stack, Joint Custody, Feminism and the Dependency Dilemma, 2 BERKELEY WOMEN's L.J. 9 (1986) (favoring joint custody because it promotes ideology of shared responsibility for children by mothers and fathers), we agree about the importance of rhetoric in influencing substantive results.

6. Carl Schneider describes individual rights as "self-concerning." Schneider, Rights Discourse and Neonatal Euthanasia, 76 Calif. L. Rev. 151, 162-64 (1988); see also Sherry, An Essay Concerning Toleration, 71 MINN. L. REv. 963, 964 (1987) (rights theory "encourages selfishness rather than altruism or community-mindedness"). This theme also runs through much of the critical legal studies critique of rights. See, e.g., Gabel, The Phenomenology of Rights-Consciousness, 62 TEx. L. REv, 1563, 1577 (1984); Lynd, Communal Rights, 62 TEx. L. Rev. 1417, 1418 (1984).

7. A woman who opts for "nonmarital motherhood-by-choice" purposefully becomes pregnant with the intention of raising the child without interference from or further involvement by the child's genetic father. See Donovan. The Uniform Parentage Act and Nonmarital Motherhood-by-Choice, 11 N.Y.U. Rev. L. \& Soc. Change 193, 193 n.1 (1982-1983). 
ings of the law-especially the kind of arguments the law urges the participants to make, and the construction of the parent-child relationship (and the concept of "the good parent") those arguments foster.

I propose that we attempt to re-direct the law applicable to disputes over parental status toward a view of parenthood based on responsibility and connection. The law should force parents to state their claims, and courts to evaluate such claims, not from the competing, individuated perspectives of either parent or even of the child, but from the perspective of each parent-child relationship. And in evaluating (and thereby giving meaning to) that relationship, the law should focus on parental responsibility rather than reciprocal "rights," and express a view of parenthood based upon the cycle of gift rather than the cycle of exchange. ${ }^{8}$

Although this article joins the contemporary, seemingly endless debate about rights, ${ }^{\circ}$ it is not a broad attack on rights. Perspectives aided by "rights talk" enhance the desired meanings of certain kinds of legal disputes. Patricia Williams has eloquently explained how civil rights doctrines have given voice to wrongs that otherwise seemed beyond reach, and justified results that otherwise seemed unwarranted. ${ }^{10}$ Rights talk is not always, however, the most appropriate voice. Legal disputes over parenthood are an example of how the presentation of claims in terms of

8. I emphasize similar values in defending joint custody options in child custody cases at divorce in Bartlett \& Stack, supra note 5, at 8; see also M. BALL, supra note 1 , at 13 (contrasting market cycle of exchange and consumption with gift cycle of increase and relationship); Finley, Transcending Equality Theory: A Way Out of the Maternity and Workplace Debate, 86 Colum. L. Rev. 1118, 1171-72 (1986) (urging ideal of responsibility in debate about pregnancy).

9. Family law scholars have criticized existing rights doctrines from many angles. Some critics find these doctrines morally defective or destructive of the family. See, e.g., M. GLENDON, supra note 1; P. Riga, Marriage and Family Law: Historical, Constitutional, and Practical PerSPECTIVES 135-41 (1986); Hafen, The Constitutional Status of Marriage, Kinship, and Sexual Privacy-Balancing the Individual and Social Interests, 81 MICH. L. REv. 463 (1983); Schneider, Moral Discourse and the Transformation of American Family Law, 83 Mich. L. Rev. 1803 (1985) [hereinafter Schneider, Moral Discourse]. Other scholars find the premises of rights arguments false, in that they assume individuals who are atomistic and self-contained rather than connected and interdependent. See Finley, supra note 8, at 1159-61; Minow, "Forming Underneath Everything That Grows": Toward a History of Family Law, 1985 WIs. L. REv. 820, 893 [hereinafter Minow, "Forming Underneath Everything That Grows"]; Minow, Rights for the Next Generation: A Feminist Approach to Children's Rights, 9 Harv. Women's L.J. 1, 14-21 (1986). Still others criticize the false pretense of objectivity and determinacy of rights, see Olsen, Statutory Rape: A Feminist Critique of Rights Analysis, 63 TEx. L. REv. 387, 391, 412 (1984), and the tendency of rights discourse to alienate people and mislead them into accepting socially constructed phenomena as inevitable. Schneider, The Dialectic of Rights and Politics: Perspectives from the Women's Movement, 61 N.Y.U. L. REv. 589, 595 (1986) [hereinafter Schneider, The Dialectic of Rights and Politics].

A few family law scholars, sensitive to both the constructive potential of rights and the validity of the criticisms against them, have suggested possibilities for radically redefining the meaning of rights. Martha Minow, for example, urges that we view rights as tools for establishing connections and relationships as well as individual prerogatives, and that we move from an understanding of rights as fixed and determinate principles, to redefine rights as perpetuating, "evolving and adaptive" tools for expressing human aspirations. Minow, Interpreting Rights: An Essay for Robert Cover, 96 YAlE. L.J. 1860, 1876, 1888, 1891-93 (1987) [hereinafter Minow, Interpreting Rights]; see also infra text accompanying note 23 . I am pursuing the same goal as Minow, but from a different angle.

10. Williams, Alchemical Notes: Reconstructing Ideals from Deconstructed Rights, 22 HARv. C.R.-C.L. L. Rev. 401 (1987). 
individual rights may force controversies into a framework that misstates the harm to be avoided and undermines the values we should promote. I demonstrate this point in a set of cases where single parents unilaterally seek exclusive responsibility for children, although I believe it might be more generally made with respect to other kinds of family law disputes. I hope this article will encourage an invigorating reevaluation of how we use rights doctrines throughout family law and, where appropriate, a reexpression of the values of relationship which existing rights doctrines now misrepresent.

In defending a re-expression of parenthood to give greater emphasis to responsibility and less to rights, I do not mean to suggest a stark dichotomy between the two. Both express significant, in some respects complementary, dimensions of ourselves and our understandings of parenthood. In the case of rights, the law engages us in an active, empowering, and self-affirming way; in the case of responsibility, the law motivates our ethical sensibilities, our motivation to "do right." I I do not reject either dimension. Rather, I argue that the rights dimension expressed in our law of parenthood is out of proportion to the responsibility dimension, and that (continual) readjustments are needed.

Likewise, I do not claim that responsibility and connection are the only values worth promoting through our rules about parenthood and child custody. I start with these values because they are compelling and because they are submerged within the exchange view of parenthood that now dominates our discourse. Other values-avoidance of prolonged custody conflicts, ${ }^{12}$ predictability of results, ${ }^{13}$ economic and physical security within families, ${ }^{14}$ the de-subordination of women, ${ }^{15}$ and even fairness to

11. See L. Petrazycki, Law and Moraliry 121 (H. Babb trans. 1955, orig. work pub. 1904-1910) ("Law, in conformity with its imperative-attributive nature, is characterized by bilateral motivational action: side by side with passive ethical motivation (the consciousness of a duty) there is active ethical motivation (the consciousness of being empowered and endowed), and the result is individual and mass conduct correspondingly coordinated.").

Rights and responsibility do not form a neat dichotomy also in the sense that claims based upon responsibility are easily restated in terms of rights. See infra text accompanying notes 197-198.

12. See J. Goldstein, A. Freud \& A. Solnit, Beyond the Best Interests of the Child 31-49 (2d ed. 1979) [hereinafter BEYOND THE BEST INTERESTS].

13. See Mnookin, Child-Custody Adjudication: Judicial Functions in the Face of Indeterminacy, 39 Law \& Contemp. Probs. 226, 262-68 (Summer 1975); Mnookin \& Kornhauser, Bargaining in the Shadow of the Law: The Case of Divorce, 88 YAlE L.J. 950, 969-71, 975, 977-80 (1979).

14. See M. Edelman, Families in Peril: An Agenda for Social Change (1987); K. Keniston, All Our Children: The American Family Under Pressure (1977); see also Wald, State Intervention on Behalf of "Neglected" Children: Standards for Removal of Children from Their Homes, Monitoring the Status of Children in Foster Care, and Termination of Parental Rights, 28 STAN. L. Rev. 623, $646 \mathrm{n} .112$ (1976) (arguing in favor of shifting funds now spent on foster care to meeting physical needs of children).

15. The problem of the de-subordination of women is of special interest to me. Later, I suggest how the value of responsibility within the parent-child relationship relates to this and other feminist goals. See infra text accompanying notes 200-01. 
parents ${ }^{16}$ - should also be debated and analyzed in terms of their relative importance and how the law's rhetoric might promote them.

The discussion I propose involves fundamental questions about who we are as a society and what it means to be part of our community. For many of us, this debate implicates contrary impulses-a longing for community and a desire for freedom from that community. We want a society in which parents share the highest norms of what the parent-child relationship should be, but we also want parents to be free to raise their children in their own way. Struggles over balancing these goals are political struggles, which have outcomes that are historically contingent and temporary. That there are no universally "correct" answers, however, does not mean that we should not approach these questions as if there are "better" and "worse" answers for us, at this time. We can, from the position of our particular, constantly moving contexts, construct improved meanings for our relationships with one another. ${ }^{17}$ This article represents one effort to do so.

\section{Rights and Responsibilities in the Theory of Parenthood}

\section{A. Parenthood as Exchange}

Since the earliest days of the modern liberal state, parenthood has been expressed in terms of exchange: Parents have rights with respect to their children in exchange for the performance of their parental responsibilities. Sir William Blackstone, John Locke, and Samuel Pufendorf, for example, all state that the rights or powers of parents arise from their duties in caring for their offspring. ${ }^{18}$ As Locke writes, "the Power . . . that Parents have over their Children, arises from that Duty which is incumbent upon them, to take care of their Off-spring, during the imperfect state of Childhood."19

16. The view that parents' rights should be the focus of child custody law is represented most recently in Elster, Solomonic Judgments: Against the Best Interest of the Child, 54 U. CHI. L. REv. 1, 16-21 (1987); see also Chambers, Rethinking the Substantive Rules for Custody Disputes in Divorce, 83 MICH. L. REv. 477, 499-503 (1984) (reviewing reasons why society might wish to prefer parents' interests).

17. This view is similar to the concept of "positionality" set forth by Linda Alcoff in addressing the essentialist/post-structuralist epistemological impasse of feminist theory. Alcoff, Cultural Feminism Versus Post-Structuralism: The Identity Crisis in Feminist Theory, 13 Signs 405, 434 (1988) (arguing that "[t]he position of women is relative and not innate, and yet neither is it 'undecidable." ").

18. See 1 W. Blackstone, Commentaries *452; J. Locke, Two Treatises of GovernMENT 348-49 (2d Treatise $§ 58$ ) (P. Laslett rev. ed. 1960) (3d ed. 1698); S. Pufendorf, Of THE LAW OF NATURE AND NAtTons 112 (Oxford trans.) (1703).

19. J. Locke, supra note 18; see also id. at 329 (2d Treatise $\S 66$ ) ("God having made the Parents Instruments in his great design of continuing the Race of Mankind, and the occasions of Life to their Children, as he hath laid on them an obligation to nourish, preserve, and bring up their Offspring."); id. at 328 (Second Treatise § 65) ("Nay, this power so little belongs to the Father by any peculiar right of Nature, but only as he is Guardian of his Children, that when he quits his Care of them, he loses his power over them ... to which it is inseparably annexed ...."). 
The exchange view of parenthood is based upon the reciprocity of parental rights and duties. ${ }^{20}$ Parents have rights that create obligations and obligations that create rights. Within this circular, self-reinforcing cycle of exchange, rights are emphasized, strengthened by their justification in obligation. Indeed, the reciprocal connection to obligation seems to make rights themselves morally compelled. As a consequence, parents asserting rights to children may construe their obligations not as independent duties or expectations, but as the moral underpinning of their rights. "Having rights" means to be entitled to, to be owed, to have earned, or to deserve something in exchange for who one is or what one has done.

As is the case with other individual rights claims, parents asserting rights to children tend to emphasize what is due to them rather than what they owe to others. As Carl Schneider has observed, "thinking in terms of rights . . . encourages us to think about what constrains us from doing what we want, not what obligates us to do what we ought."21 The rights generated within this view stress entitlement over responsibility, autonomy over connectedness, self over others. ${ }^{22}$ Rights claims tend to exalt the "my" over the "ours," the "I" over the "we."

It may be possible, as Martha Minow argues, to alter our understandings of rights so that they express community and interconnection, in addition or in preference to individualism and separateness. ${ }^{23}$ Thus, we might redefine parental rights to stress the parent's relationship interests, rather than the parent's autonomy. Even then, the focus is on what belongs to the parent rather than how the parent belongs to others. In any event, whether we revolutionize what we mean by parental rights or move beyond them, we need to take a fresh, concentrated look at the alternative meanings of parenthood that are available to us.

\section{B. Parenthood as Responsibility Within Relationship}

Responsibility and relationship are difficult terms to pin down. They are evolving rather than fixed concepts, constituted by the attitudes and responses of those engaged, through practice, in living out their meanings. ${ }^{24}$ These attitudes and responses, of which law is a part, form a con-

20. See Chapsky v. Wood, $26 \mathrm{Kan} .650,652$ (1881) ("because of this obligation to take care of and support this helpless being arises a reciprocal right to the custody and care of the offspring whom he must support. . . .").

21. Schneider, supra note 6, at 37; see also Schneider, Moral Discourse, supra note 9, at 1858 ("the rights approach must be ... hostile to moral discourse, because the resolution of moral problems must commonly be particularistic and delicate, while the promulgation and enforcement of rights is often generalistic and insensitive to nuance").

22. See supra note 6.

23. In articulating this more fluid understanding of rights doctrine, Professor Minow stresses the importance to rights-bearing individuals of "social networks" and "roles connecting with others." Minow, "Forming Underneath Everything That Grows," supra note 9, at 894; see also Schneider, The Dialectic of Rights and Politics, supra note 9, at 617-22.

24. See Watson, Responsibility and the Limits of Evil: Variations on a Strawsonian Theme, in 
tinuous, ongoing process. In this section, I outline some of the important dimensions of a concept of responsibility that might be expressed through the law's handling of parenthood disputes.

\section{Responsibility, Relationship, and Identification}

Although some notions of social responsibility have associated duty or obligation with individual autonomy, ${ }^{25}$ responsibility - as I use the term here-is grounded in relationship rather than autonomy. Responsibility describes a certain type of connection that persons may experience in their relationships with one another. That connection is one of identification. Identification requires a "[r]ecognition of the other person's reality, and the possibility of putting yourself in his place . . ."28 Identification must be positive and affirming; it seeks what is good for the other person. ${ }^{27}$

The experience and meaning of responsibility may be quite personal and individualized. Its meaning, however, is derived within a social context that defines ideal roles for persons engaged in particular relationships. ${ }^{28}$ Thus, while individuals to a certain extent choose the terms of their own relationships, the choices they make and the meaning given to those choices are strongly shaped by role expectations defined by the community. At the same time, responsibility means more than fulfilling some precise set of pre-defined role requirements. A responsible person cares not only about doing "her part" (or "his part") in a limited sense, but also about outcome, and is disposed toward expanding or perhaps redefining the demands of role as necessary to accomplish that outcome. Responsibility, in other words, is a self-enlarging, open-ended commitment on behalf of another.

Parenthood illustrates well the wide spectrum of commitments one may make in fulfilling one's role responsibility. As a parent, one may do what one thinks is expected of a person in that role, applying one's best instincts and perhaps even book-learning to guide the child from infancy

Responsibility, Character, and the Emotions 256 (F. Schoeman ed. 1987).

25. See Gilligan, Remapping the Moral Domain: New Images of the Self in Relationship, in RECONSTRUCTING INDIVIDUALISM: AUTONOMY, INDIVIDUALITY, AND THE SELF IN WESTERN Thоught 237 (T. Heller, N. Sosna, \& D. Wellbery eds. 1986) (using Aeneid to illustrate "long history" in western tradition of connection between social responsibility and "the representation of the self as separate and bounded").

26. This language is from Thomas Nagel's description of altruism. T. NAGEL, ThE PossibILITY of Altruism 83 (1970); see also N. Noddings, Caring: A Feminine Appronch to Ethics and Moral Education 14 (1984) ("When I look at and think about how I am when I care, I realize that there is invariably this displacement of interest from my own reality to the reality of the other.").

27. James Wallace describes this quality as benevolence: "A benevolent person is not concerned merely about avoiding certain forms of behavior that he regards as wrong: he is directly concerned for the good of other people." J. WALLACE, VIRTUES AND Vices 130 (1978).

28. See H.L.A. Hart, Punishment and Responsibility 212-13 (1968) (describing "roleresponsibility"); Hamilton, Who Is Responsible? Toward a Social Psychology of Responsibility Attribution, 41 Soc. Psychology 316 (1978) (role expectations form context for exercise of responsibility, rather than acting as external constraint). 
into a mature and productive adulthood. But a parent who refrains from a personal commitment to how the child "turns out" has not assumed full responsibility for that relationship. The responsible, child-identified parent is inclined to intepret the role of parent broadly and flexibly, and is satisfied only when the child has "turned out" well.

\section{Responsibility, Freedom, and Obligation}

The identification that responsibility entails develops within a context in which both coercion and freedom are essential. Responsibility connotes obligation. Obligation, of course, may be cheerfully, as well as reluctantly, assumed. But even voluntary acts can be judged according to some normative (whether objective or subjective) standard, and to the extent that this standard directs a person's conduct, we might say that that conduct has been coerced.

Responsibility also, however, connotes freedom. Indeed, at the core of the notion of responsibility is the exercise of discretion: ${ }^{30}$ Authentic responsibility can develop only where a person is free to act virtuously or not." "To act virtuously is not . . . to act against inclination; it is to act from inclination formed by the cultivation of the virtues."32

The conflicting notions of freedom and compulsion that are embedded in the concept of responsibility encapsulate the dialectic tension that philosophers and commentators have found to be bound up in our basic notions of selfhood. ${ }^{33}$ Nel Noddings, in her work on an ethic of caring, deals with this tension specifically in the context of close, personal relationships. Noddings finds a basis for free action in our longing for caring and relationship, which motivates us to do what we ought to do to maintain caring

29. What it means to "turn out" well, of course, depends upon one's values and the values of one's social group. See Ruddick, Maternal Thinking, in Mothering 213, 220 (J. Trebilcot ed. 1984). The point here is that whatever social norms about growing up to be an "acceptable" adult exist, a parent who has truly taken responsibility for a child cares deeply about that child's ultimate development. (S)he will not be satisfied merely to have discharged her/his duty in the eyes of others.

30. See Pennock, The Problem of Responsibility, in ResponsibILITY (Nomos III) 3, 4 (C. Friedrich ed. 1960).

31. Freund, Responsibility-Definitions, Distinctions, and Applications in Various Contexts in RESPONSIBILITY (NOMOS III), supra note 30, at 28, 37. I refer here not so much to the absence of culpability for acts done by a person in some way coerced, but also to the absence of moral credit due to a person who acts under compulsion. Both of these dimensions are discussed in Fischer, Introduction: Responsibility and Freedom, in MORAL ResPonsIBILITY 9, 9-14 (J. Fischer ed. 1986).

32. A. Macintyre, After Virtue 140 (1981); see also Seneca, On Benefits (Epistle), ll. 20-24 in 2 Seneca, Epistulae Morales 218, 231-32 (R. Grummere trans. 1970) ("honourable benefactor" acts not "because it profits me, but because it pleases me").

33. See S. Fish, Doing what Comes Naturaliy: Change, Rhetoric and the Practice of Theory in Legal and Literary Studies (1989) (forthcoming) (comparing Milton's concept of "willing followers" with Unger's concept of freedom acquired through being bound to one's community); M. Taylor, Journeys to Selfhood: Hegel \& KiekegaArd 174-76, 243-47 (1980) (analyzing ways in which Kierkegaard and Hegel resolved tension within self between freedom and necessity); Michelman, Political Markets and Community Self-Determination: Competing Judicial Models of Local Government Legitimacy, 53 IND. L.J. 145, 150 \& n.28 (1977-1978) (analyzing how Kant and Rousseau linked freedom of self with goals and values emanating from community). 
relationships. ${ }^{34}$ Her vision is an "I must" constrained by "our best picture of ourselves." 35 Within the context of the parent-child relationship, Noddings' concept of caring suggests that parents are free to (and should) bind themselves to act according to their most ennobled sense of what parenthood requires. This binding occurs within a social milieu which creates and sustains the ideals that parents internalize as part of their "ennobled selves."

In this sense, responsibility is a form of self-expression. ${ }^{38}$ Responsible action is chosen, but that choice expresses a particular set of internalized limits and constraints that define the person. This expression provides to the individual a sense of his or her own particularity that is essential to the subjective freedom required for moral decision-making. ${ }^{37}$ The moral growth that comes from being held accountable for one's actions, in turn, derives at least in part from the perception that one's actions are voluntary. The choice to act morally is self-reinforcing, creating momentum for acting morally on the next occasion, and the next, and strengthening the foundation upon which future moral actions will be based. ${ }^{38}$

The role of law in forming the social context within which parents might internalize high ideals for responsibility and voluntarily proceed to act upon them is a tricky one. Somehow the law must contribute to the creation of high expectations for parents, while leaving sufficient leeway so that parents are free to become responsible in the true sense. A handsoff approach by the law to questions of parenthood would abdicate any societal responsibility for norms of parenthood; yet a tight, comprehensive set of controls would remove from parents the discretion to act, upon which the capacity of moral decisionmaking actually depends.

Certain practical problems in regulating the behavior of parents toward their children compound the difficulties for law. Parenting is both a decentralized and a continuous activity. Good parenting depends upon the quality of hundreds of daily acts with respect to children. ${ }^{39}$ The state sim-

34. N. Noddings, supra note 26 , at 5 .

35. Id. at 80 .

36. See J. Dewey, Outlines of a Critical Theory of Ethics 160-61 (1957) ("We are responsible for our conduct because that conduct is ourselves objectified in actions."). The theme of responsibility as self-expression through obligation and service to others (or the Other) permeates Christian theology; see, e.g., H. Niebuhr, The Responsible SElf 126 (1963) ("Responsibility affirms: 'God is acting in all actions upon you. So respond to all actions upon you as to respond to his action." ").

37. See F. Hegel, Philosophy of Right, II 183-88, 207-08 (T. Knox 1967) (1821). My reading of Hegel on this point is derived from J. Blustein, PARENTS and Children 93-95 (1982).

When the person cared for experiences the exercise of another's responsibility as voluntary, the relationship becomes one that is affirming to both parties. See Hafen, supra note 9, at 499. Further, responsibility motivates reciprocal commitments and loyalties that strengthen the underlying relationship. See Karst, The Freedom of Intimate Association, 89 YALE L.J. 624, 633 (1980).

38. See L. Petrazycki, supra note 11, at 301 (repetition of moral acts influences capacity and motivation to act morally in future).

39. Hafen, supra note 9 , at 473 . 
ply does not have the capacity to supervise such activity. ${ }^{40}$ Further, parenting is an enterprise about which rules are of only very limited utility to parents. The contexts within which parenting must take place are defined by particularities that defy the kind of generalization upon which rule-systems are based. A parent can find it next to impossible to apply rules-even the parent's own rules-to every specific situation. Instead, responses to situations must depend upon judgment developed through experience and example. Although rules help convey societal meaning to parents about what generally is expected from them, these rules can do little to cultivate a more universal judgment.

I explore how the law might best contribute to defining a norm of responsibility while still preserving maximum parental freedom and judgment in context of specific custody conflicts. Before doing so, however, I discuss briefly how my emphasis on the law's expressive effects relates to the standard for resolving child custody disputes that is often contrasted with parental rights-the "best interests of the child" test. Then, I address the conflict between the community and the individual that is inherent in my project to identify the societal norms the law should express.

\section{Responsibility and the Best Interests of the Child}

It is reasonable to ask at this point whether my focus on the law's effects on promoting parental responsibility for children represents any sort of improvement on the best interests of the child standard. Is not the concern for the responsibility of parents derived, after all, from our concern for the welfare of children? And although substitute standards that make the best interests of the child test more precise and administrable might be welcome, ${ }^{41}$ isn't the standard of parental responsibility urged here even more open-ended and amorphous?

In addressing this issue, I should note, first, that the best interests of the child standard represents a considerable ideological and rhetorical advancement over child custody standards that focus on the parents' interests. Forcing parents to articulate their claims to children in terms of the child's welfare expresses a societal preference for protecting children over

40. BeYond the Best INTEREsts, supta note 12 , at 49-52.

41. The well-known proposals of Joseph Goldstein, Anna Freud and Albert Solnit are one example of an effort to give concrete and practical meaning to the open-ended objective of serving the best interests of children (or, as these authors put it, "the least detrimental alternative"). J. GoudDStEIN, A. Freud \& A. Solntt, Before the Best Interests of the Child 4, 12 (1979) [hereinafter BEFORE THE BEST INTERESTS] (policy of minimum state intervention accords with professional understanding of interests of child); BEYOND THE BEST INTERESTS, supra note 12, at 7-8 (reconciling value preference in favor of holding child's needs paramount, and right of parents to raise their children with minimum state intervention); see also Mnookin, supra note 13, at 292 (urging limitations on judicial discretion when courts exercise child-protection function, because indeterminacy of best interests of child test is "unjust and unwise"); Wald, supra note 14, at 992 (justifying presumption in favor of parental autonomy both because of political commitment to diversity of lifestyles, and because such a presumption "comports with our limited knowledge regarding childrearing"). 
protecting adults, a preference which, though not inevitable, ${ }^{42}$ is easily defended. ${ }^{43}$

The best interests of the child standard, however, is not a satisfactory substitute for rights doctrine in parenthood disputes. First, in an important sense, the best interests standard merely substitutes the interests or "rights" of one party-the child-for those of others. In this sense it does not get away from rights doctrine, but rather makes the child, and not the parents, the party whose rights are paramount. ${ }^{44}$

Further, the best interests of the child is a highly contingent social construction. Although we often pretend otherwise, it seems clear that our judgments about what is best for children are as much the result of political and social judgments about what kind of society we prefer as they are conclusions based upon neutral or scientific data about what is "best" for children. ${ }^{45}$ The resolution of conflicts over children ultimately is less a matter of objective fact-finding than it is a matter of deciding what kind of children and families-what kind of relationships-we want to have. ${ }^{10}$

42. See Chambers, supra note 16 , at $499-503$ (reviewing reasons for considering interests of parents as well as children); Elster, supra note 16 (arguing on behalf of best interests of adults).

43. See BEYOND THE BEST INTERESTS, supra note 12, at 105-11 (justifying paramouncy of child's interests); BEfORE THE BEST INTERESTS, supra note 41, at 4-5 (child's well-being, not parents', is determinative once state has intruded on family).

In their most recent work, the authors of these works use the term "ordinary devoted parent" (borrowing from D. Winicott, The Ordinary Devoted Mother and Her BABy (1949)) to describe those in whose hands we should place authority for raising children. J. GoldsteIN, A. Freud, A. Solnit \& S. Goldstein, In the Best Interests of the Child 3 (1986). Goldstein, Freud, and Solnit take the devotion of a child's parent for granted (except where clear abuse is shown), and angue that the ability to parent effectively requires broad autonomy. See supra note 41 . I agree with their emphasis on parental autonomy, but their principles are not designed to resolve disputes between biological parents of the type raised in this article. Moreover, I argue that the law has more to do than to allocate authority for children. As I try to show, the law speaks in many ways to create and sustain social values. One way of viewing my project is to define, and determine how to promote, the desired qualities of the "ordinary devoted parent."

44. See L. Houlgate, Family and State: The Philosophy of Family Law 111 (1988).

45. The best interests test has long been under attack on the grounds that its results are indeterminate. See, e.g., Charlow, Awarding Custody: The Best Interests of the Child and Other Fictions, 5 YAle L. \& PoL'Y REv. 267, 267 (1987); Elster, supra note 16, at 12-16; Mnookin, supra note 13, at 257-61. This indeterminacy, paradoxically, permits systematic bias. Feminists, for example, have attacked the best interests test because it allows judges to bring their white, middle class biases into child custody cases, biases which favor men over women. See P. Chesler, Mothers on Trial: The BATTLE fOR Children and CuSTOdy 239-68 (1978); Polikoff, Why are Mothers Losing: A Brief Analysis of Criteria Used in Child Custody Determinations, 7 Women's RTs. L. RPTR. 235, 237-39, 241 (1982); Sheppard, Unspoken Premises in Custody Litigation, 7 Women's Rts. L. Rptr. 229, 233 (1982); Uviller, Fathers' Rights and Feminism: The Maternal Presumption Revisited, 1 Harv. WOMEN's L.J. 107, 121-26 (1978). Other commentators have emphasized the systematic bias against poor and minority families. BEFORE THE BEST INTERESTS, supra note 41 , at 17; Wald, supra note 14 , at 629.

46. See C. Smart, The Ties That Bind: Law, Marriage and the Reproduction of PaTrIARChal Relations 120-27 (1984); Bartlett \& Stack, supra note 5, at 10-11; Dingwall \& Eekelaar, Judgments of Solomon: Psychology and Family Law, in CHILDREN OF SOCIAL WORLdS 54 (M. Richards \& P. Light eds. 1986); Fineman \& Opie, The Uses of Social Science Data in Legal Policy Making: Custody Determinations at Divorce, 1987 WIs. L. REv. 107, 157-58; Morgan, Making Motherhood Male: Surrogacy and the Moral Economy of Women, 12 J. L. \& Soc. 219, 223 (1985); Zipper \& Sevenjuijsen, Surrogacy: Feminist Notions of Motherhood Reconsidered, in REPRoDuCrIvE TeChnologies: Gender, Motherhood and Medicine 118, 132 (M. Stanworth ed. 1987) (here- 
Finally, we care about the workings of these relationships not solely because we care about children, but also because we care about the kind of society in which we live. We want a society in which parent-child relationships are strong, secure, and nurturing. If we have to choose between children and adults, we may prefer to be a society which puts the child's interests first, but our larger concern is how the interests of both parent and child link together in relationships. Responsibility is a critical dimension of these relationships. Parents being responsible for children, in other words, fits the best picture we have of ourselves.

\section{Responsibility, the Community, and the Individual}

There is an extensive body of literature exploring the relationship between collective or communitarian definitions of the good and the rights of the individual, ${ }^{47}$ which I cannot fully address here. A few general observations will help, however, in locating my article within that debate.

When I speak of societal construction of parenthood, I refer to a process of community norm-building about what it means to be a parent. This process might lead to the prohibition of individual choices. Communities can be repressive. ${ }^{48}$ Thus individuals must, and do, sometimes resist, fending off the community as it attempts to shape individuals to its own vision. ${ }^{48}$ But the community is not all we have to fear. As I try to show in

inafter ReProductive TechNologies].

This is not to suggest that social science data cannot be relevant. Once the necessary political choices are made, the behavioral sciences may offer us useful information about how to achieve the goals we have set for ourselves. See Melton, Developmental Psychology and the Law: The State of the Art, 22 J. FAM. LAW 445 (1983-84) (describing current role of developmental psychology in informing legal determinations relating to children).

47. Some of the major examples of this literature include M. SANDEL, Liberalism AND THE Limirs of Justice (1982) (challenging deontological liberalism, which is based on view of society as collection of individuals organized according to principles that do not presuppose any particular conception of the good, in favor of constitutive view of community); R. UNGER, KNOWLEDGE AND Polrtics 213-22 (1975) (expressing theory of self or individual in relation to community); Gutmann, Communitarian Critics of Liberalism, 14 PHIL. \& PUB. AFF. 308 (1985) (responding to communitarian critics of liberal political theory); Kennedy, The Structure of Blackstone's Commentaries, 28 BufFALO L. REv. 28 (1979) (demonstrating how within every legal problem, "the goal of individual freedom is at the same time dependent on and incompatible with the communal coercive action that is necessary to achieve it"); Michelman, Foreword: Traces of Self-Government, 100 HARv. L. REv. 4, 21-24 (1986) (describing tensions within republican tradition between self-interest of individual and values of community); Michelman, Justification (and Justifiability) of Law in a Contradictory World, in Justification Nomos XXVIII 71 (J. Pennock \& J. Chapman eds. 1986) (asserting need for justifiability of law notwithstanding inherent contradictions between individual freedom and collective action) [hereinafter Michelman, Justification (and Justifiability)]; Minow, Interpreting Rights, supra note 9 (developing theory of rights that recognizes values of community and responsibility); Sherry, Civic Virtue and the Feminine Voice in Constitutional Adjudication, 72 VA. L. REv. 543 (1986) (contrasting modern individualist and classical teleological paradigms); Sunstein, Interest Groups in American Public Law, 38 STAN. L. REv. 19 (1985) (tracing historical roots of republicanism and its competing models for reconciling interests of individuals with general good).

48. For an extreme, chilling account of a repressive societal redefinition of parenthood, see $M$. ATWOOD, A HANDMAID's TAlE (1985).

49. Family law is rich with explicit examples of the successful resistance of individuals to efforts of the community to standardize its members. See, e.g., Moore v. City of E. Cleveland, 431 U.S. 494, 506 (1977) (plurality opinion) ("the Constitution prevents East Cleveland from standardizing its chil- 
this article, the single-minded focus on the rights of individuals creates its own dangers, with implications not only for those individuals but for the community as well. The struggle between the community speaking in a common voice and individuals speaking in many voices is a struggle inevitable in any society that attempts to set itself on liberal foundations. Because the interests of the individual and the will of the community are necessarily in tension, the argument that individual interests (or the will of the majority) is compromised can never constitute a final refutation of a proposed solution to a political problem. ${ }^{\text {so }}$

Within the liberal society, part of the tension between individual and community is relieved by the willingness of the community to set limits on its repressive capacities. To resist the "tyranny of the majority," the liberal community provides mechanisms by which the community evaluates the claims of individuals. And to the extent that the community's rules recognize the claims of individuals against the majority and respect individual lifestyles and conceptions of responsibility, those claims in an important sense are rooted in the community. Tolerance of individual choices, then, becomes part of the community's self-definition.

Reconciliation between the community as a collection of individuals, and individuals who necessarily find themselves in community, also comes as individuals struggling to achieve their own notions of responsibility internalize the norms and restraints of the community. This process, with all of its tensions and conflicts, reflects our dual nature as both individuals and social beings. We seek freedom within a community tht limits our choices. ${ }^{51}$ We are potential agents of resistance in a community which

dren-and its adults-by forcing all to live in certain narrowly defined family patterns"); Roe v. Wade, 410 U.S. 113 (1973) (state may not override individual rights of pregnant woman to choose abortion by adopting one theory about when life begins); Wisconsin v. Yoder, 406 U.S. 205, 223-24 (1972) (in finding compulsory education laws to be unconstitutional violation of rights of Amish parents to direct upbringing and education of their children, Court states: "There can be no assumption that [the state's] majority is 'right' and the Amish . . . are 'wrong." "); Pierce v. Society of Sisters, 268 U.S. 510, 535 (1925) (individual rights of parents abridged when state attempts to "standardize its children by forcing them to accept instruction from public teachers only"); Meyer v. Nebraska, 262 U.S. 390, 399-402 (1923) (desire of state legislature to foster homogeneous people by forbidding foreign language instruction before eighth grade must give way to fundamental individual rights). But see Bowers v. Hardwick, 106 S. Ct. 2841 (1986) (individual rights of homosexual individuals do not outweigh interests of majority of Georgia legislature in enforcing its moral standards through criminal sodomy statutes).

50. This is not to imply that the individual and the community are necessarily in direct conflict, or that our choice is between the individual and the community. See Gutmann, supra note 47 (rejecting dualistic thinking which assumes that we are constituted either as individuals or as members of communities). It is, rather, to say that recognizing either the interests of the individual or the will of the community will have unavoidable implications for the other.

51. Frank Michelman puts this point in the most positive possible light when he responds to Duncan Kennedy's "heroic, mind-numbing[]" expose of the inherent contradictions of liberal legal principles: "Duncan Kennedy's diagnosis of liberal legal pathology rests on the claim that the contradiction is, for us, an experience fearful and painful. That is not how it seems to me. I think the contradiction is my friend; nay, my self." Michelman, Justification (and Justifiability), supra note 47, at 94; see also Sparer, Fundamental Human Rights, Legal Entitlements, and the Social Struggle: A Friendly Critique of the Critical Legal Studies Movement, 36 STAN. L. REv. 509, 547 (1984) (dis- 
itself has formed us. We cannot resolve these tensions, but we must confront them as we address the here-before-us human conflicts that come to the law for answers.

\section{Mothers Choosing Nonmarital Parenthood}

For women who either do not find or do not choose conventional, heterosexual relationships within which to have children, a possible alternative is "nonmarital motherhood-by-choice." Their ability to pursue this alternative can be frustrated in many ways. In this section, I begin by sketching the disputes that may arise and the current legal framework for resolving such disputes. I then set forth and evaluate specific legal claims on behalf of nonmarital motherhood-by-choice. For the most part, these claims are assertions of right that reflect the exchange view of parenthood, and give little if any attention to the societal meanings attached to parenthood. Finally, I explain how, in approaching the issues raised by nonmarital motherhood-by-choice, we might attempt to develop more desirable meanings of parenthood based upon the concept of responsibility within relationship developed in Part II.

\section{A. The Legal Background}

Unmarried women claiming parental rights without interference from the child's biological father run head-on into a legal tradition in family law that assumes that every child should have two parents. ${ }^{52}$ The law has not always insisted that these two parents be treated equally with respect to custody, especially where the parents are unmarried. In many states mothers have superior custodial rights ${ }^{53}$ and fathers, to have any rights at all, need to take steps to perfect their rights that mothers need not take. ${ }^{.4}$ But if a father is intent upon doing so, he will ordinarily be able to assert

cussing interdependence of notions of individual autonomy and community).

52. See K. Bartlett, The Rule of Two Parents (1987) (unpublished manuscript).

53. See, e.g., Allen v. Childress, 448 So. 2d 1220 (Fla. Dist. Ct. App. 1984) (mother is natural guardian of child); OKLA. STAT. tit. $10 \S 6$ (1981), interpreted in In re Adoption of Baby Boy D., 742 P.2d 1059, 1068 (Okla. 1985) ("The mother of an illegitimate minor is entitled to its custody."); 14 VT. STAT. ANN. $\$ 2644$ (Supp. 1988) (mother of illegitimate child is child's guardian); see also Kuhmer v. Gibson, No. 81-924 (Ohio Ct. App. filed September 30, 1981) ("The mother of an illegitimate child is its natural guardian and has the legal right to custody, care and control of such child superior to the right of the natural father, or any other person, and is legally responsible for the care and support of the child.") (citing In re Gutman, 22 Ohio App. 2d 125 (1969)).

54. For example, an unwed father may be required to acknowledge or legitimate his child formally, or otherwise demonstrate responsibility for the child, before he will be afforded any rights to the child. See, e.g., Smith v. Watson, 425 So. 2d 1030, 1033 (Miss. 1983) ("all things being equal ... the mother of an illegitimate child, if the mother is a suitable person, has the primary right to the child's custody . . . U Upon acknowledging the child as his own, the father has an equal claim, with the mother, to the parental and custodial rights to the child."); GA. CODE ANN. § 19-7-25 (Supp. 1988) ("[o]nly the mother of an illegitimate child is entitled to his custody, unless the father legitimates him ..."); see also infra text accompanying notes 97-99 (describing rules limiting fathers' rights in adoption cases, unless father has taken steps to perfect his interests that mother is not required to take). 
some parental rights over the objection of a mother who seeks to raise the child without him. ${ }^{55}$ In the event the mother seeking nonmarital motherhood-by-choice is a lesbian, the father may even win primary custody of the child. ${ }^{\text {so }}$

An unmarried woman who seeks to conceive her child through artificial insemination may seek application of the general rule that prevents sperm donors from acquiring the legal rights and obligations of parenthood. Most statutes creating this rule, however, apply only to children born of married women. ${ }^{\text {sz }}$

One option for the unmarried woman is a formal agreement with the sperm donor that he will have no rights or obligations with respect to the child. Contracts explicitly releasing parents from support obligations, however, are generally considered to be unenforceable as contrary to public policy ${ }^{58}$ Moreover, such contracts might well constitute evidence of paternity, thus hindering rather than facilitating the mother's ability to establish exclusive parental rights and obligations. ${ }^{50}$

Use of anonymous donors would be another possible solution for women seeking exclusive parenthood: If no father can be identified, none can be imposed. Anonymity, however, requires the involvement of a reliable third party, and, if the woman prefers an established clinic, usually a doctor. Some statutes, indeed, provide that artificial insemination may be performed only under the supervision of a physician. ${ }^{60} \mathrm{~A}$ woman who

55. See H. Clark, Jr., The Law of Domestic Relations in the United States 199-200 (2d ed. 1988) (citing numerous cases).

56. Cases dealing with the issue of the fitness of an openly gay parent for custody of a child are split. Some cases have held that a parent's homosexual activities should not be taken into account in a child custody decision unless an adverse effect of these activities on the child is shown. See, e.g., D.H. v. J.H., 418 N.E.2d 286 (Ind. App. 1981); Peyton v. Peyton, 457 So. $2 d 321$ (La. App. 1984); Doe v. Doe, 16 Mass. App. Ct. 499, 452 N.E.2d 293 (1983); Guinan v. Guinan, 102 A.D.2d 963, 477 N.Y.S.2d 830 (1984). But other cases assume that a parent's homosexual lifestyle is damaging to a child. See, e.g., G.A. v. D.A., 745 S.W.2d 726 (Mo. App. 1987); Jacobsen v. Jacobsen, 314 N.W.2d 78 (N.D. 1981); M.J.P. v. J.G.P., 640 P.2d 966 (Okla. 1982); Constant A. v. Paul C.A., 344 Pa. Super. 49, 496 A.2d 1 (1985); Kallas v. Kallas, 614 P.2d 641 (Utah 1980); Roe v. Roe, 324 S.E.2d 691 (Va. 1985).

57. The Unif. Parentage Act, § 5(b), U.L.A. 301 (1987), followed in many states, provides: "[t]he donor of semen . . . for use in artificial insemination of a married woman other than the donor's wife is treated in law as if he were not the natural father of a child thereby conceived." For a comprehensive list of statutes covering artificial insemination, including those which have enacted some version of the Uniform Parentage Act, see O'Rourke, Family Law in a Brave New World: Private Ordering of Parental Rights and Responsibilities for Donor Insemination, 1 Berkeley WOMEN's L.J. 140, 144-47 (1985). O'Rourke finds only six states that seem to contemplate artificial insemination of unmarried women. Id. at 146 \& 146 n.47. See CAL. Civ. CoDE ANN. § 7005(b) (West 1983); Colo. Rev. Stat. § 19-6-106(2) (1986); N.J. Stat. ANN. § 9:17-44 (West 1983); Or. Rev. Stat. § 109.239(1) (1987); Wash. Rev. Code ANN. § 26.26.050(2) (Supp. 1985); Wyo. Stat. $\S 14-2-103(\mathrm{~b})(1986)$.

58. See Kern \& Ridolfi, The Fourteenth Amendment's Protection of a Woman's Right to Be a Single Parent Through Artificial Insemination by Donor, 7 Women's Rts. L. Rep. (Rutgers Univ.) 251, 257 n.35 (1982); Note, Contracts to Bear a Child, 66 CAlif. L. Rev. 611, 613 (1978).

59. See Kern \& Ridolfi, supra note 58, at 256; O'Rourke, supra note 57, at 160.

60. Statutes in fourteen states, including each of the six states which seem to permit artificial insemination of unmarried women, see supra note 57 , provide that the donor of semen used in artificial insemination is not deemed the natural father only where the sperm was provided to a licensed 
attempts to go through medical channels may face practical barriers. Physicians may refuse to perform artificial insemination on unmarried women, in part because of uncertainty as to its legality, ${ }^{61}$ and in part out of disapproval of the practice. ${ }^{82}$

Women seeking exclusive parenthood status, then, face considerable obstacles. Where the biological father is known, virtually every state extends legal parenthood status to that father. And where women seek anonymous donors instead, no statutes give women greater access to medical channels than doctors are willing to allow.

\section{B. Rights Claims}

\section{Claims Based on Constitutional Precedent}

Women seeking to overcome the obstacles to nonmarital parenthood-bychoice have attempted to use constitutional arguments to overcome both the legal barriers to exclusive custody and the reluctance of the medical profession to perform artificial insemination. Unmarried women have claimed a constitutional privacy right to conceive children through artifi-

physician. See O'Rourke, supra note 57, at $145 \mathrm{n} .41$. Three states allow only physicians to perform artificial insemination, or impose criminal penalties on those who perform artificial insemination without the supervision of a physician. See GA. CODE ANN. $\$ 43-34-42$ (1984) (felony); IDAHO CODE $\S \S 39-5402,39-5407$ (1985) (misdemeanor); OR. REv. STAT. $\$ \S 677.360,677.990$ (1987) (misdemeanor).

In a case decided under the California artificial insemination statute, a biological father who sought to establish paternity and to exercise visitation rights with his child prevailed because the woman had not used a doctor in her insemination procedure. Jhordan C. v. Mary K., 179 Cal. App. 3d 386, 224 Cal. Rptr. 530 (1986).

Physicians almost always use anonymous donors only. One study showed that $91.8 \%$ of physicians who perform artificial insemination will not allow the couple to select the donor, and for the others, it is a rare practice. Curie \& Cohen, Current Practice of Artificial Insemination by Donor in the United States, 300 NEw ENG. J. MED. 585, 586 (1979); see also Annas, Fathers Anonymous: Beyond the Best Interests of the Sperm Donor, 14 FAM. L.Q. 1, 10 (1980).

61. See Kritchevsky, The Unmarried Woman's Right to Artificial Insemination: $A$ Call for an Expanded Definition of Family, 4 HARv. WOMEN's L.J. 1, 3-4 (1981).

62. The basic medical text on artificial insemination states that "any display of interest in lartificial insemination] by an unmarried woman is indicative of psychological distress . . . "W. FineGOLD, ARTIFICIAL INSEMINATION 101 (2d ed. 1976).

Even where doctors do not refuse to provide artificial insemination services to unmarried women, women may feel that their "rights" to exclusive parenthood are not adequately ensured. First, the procedures in doctor's hands can be costly. See Kritchevsky, supra note 61, at 29, n.144 (citing Miller, Artificial Insemination, Boston Phoenix, June 19, 1979, sec. II, at 4, col. 1 ("Boston doctors' charges were $\$ 75$ for a pre-insemination workup and $\$ 125$ to $\$ 150$ an insemination cycle; clinics' charges ranged from $\$ 60$ to $\$ 75$.")). Moreover, having to use the services of a doctor offends those who feel that the simple, intimate procedure should be controlled by the parties involved, not third parties. See G. Corea, The Mother Machine 43-46 (1985). Not an insignificant aspect of this phenomenon is the desire by women to make a political statement that they should be able to control their own sexual lives. See G. Cassidy-Brinn, F. Hornstein \& C. Downer, Woman-Centered Pregnancy and BirTh, 3-9 (1984); A. DwORkin, Right-Wing WOMEN 183-88 (1983); Hornstein, Children by Donor Insemination: A New Choice for Lesbians, in Test-TUbe WOMEN: What Future for Motherhood 373, 377 (R. Arditti, R. Klein \& S. Minden eds. 1984); Rich, Compulsöy Heterosexuality and Lesbian Existence, in Powers of Destre: The Polrtics of Sexualrty 177 (A. Snitow, C. Stansell \& S. Thompson eds. 1983). 
cial insemination and to have exclusive rights to the child at birth. ${ }^{63}$ Advocates have read the Supreme Court's privacy cases protecting individuals against compulsory sterilization ${ }^{64}$ and against state laws limiting access to contraception $^{68}$ and abortion ${ }^{68}$ as affirming a right of procreation, available to unmarried as well as married persons. ${ }^{87}$ Another privacy argument made, which builds upon the suggestion in several Supreme Court opinions that the state may not narrowly define the concept of "family," is that an unmarried woman has the right to decide the composition of her family. ${ }^{68}$

Some commentators have also urged a right to nonmarital motherhoodby-choice on equal protection grounds. For married women who have conceived a child through artificial insemination, the general rule is that the sperm donor has no rights. Allowing the married woman to achieve parenthood exclusive of the sperm donor through artificial insemination while denying the unmarried woman the same right, the argument goes, constitutes an unconstitutional discrimination between married and unmarried women. ${ }^{60}$

These constitutional arguments are highly problematic. First, the precedents to which the privacy arguments appeal establish protection for individuals from state interference in activities relating to procreation and sexual conduct. ${ }^{70}$ While this authority might preclude a state-imposed ban on artificial insemination of unmarried women, ${ }^{71}$ it does not define an affirmative right to procreate that could be asserted against either the state when it seeks to identify two biological parents for every child, or the

63. See, e.g., Kern \& Ridolfi, supra note 58, at 283-84 (restrictions on access to professional artificial insemination facilities and judicial enforcement of mother's right to custody against claims of semen donor are unconstitutional); Kritchevsky, supra note 61, at 4-5 (arguing it would be unconstitutional to outlaw artificial insemination for unmarried women); Lacey, The Law of Artificial Insemination and Surrogate Parenthood in Ohlahoma: Roadblocks to the Right to Procreate, 22 TuLsA L.J. 281 (1987) (ban on artificial insemination for single women would be unconstitutional); Note, Reproductive Technology and Procreation Rights of the Unmarried, 98 HARv. L. Rev. 669 (1985) (arguing for constitutional right of access by unmarried women to reproductive technology); Comment, Mother Know's Best: A Constitutional Perspective on Single Motherhood by Choice, 1984 S. It.1. U.L.J. 329 (woman who chooses to be single mother has constitutional right to be free from risk of interference from biological father or state).

64. Skinner v. Oklahoma, 316 U.S. 535 (1942).

65. Griswold v. Connecticut, 381 U.S. 479 (1965); Eisenstadt v. Baird, 405 U.S. 438 (1972) (plurality opinion).

66. Roe v. Wade, 410 U.S. 113 (1973); Planned Parenthood v. Danforth, 428 U.S. 52 (1976).

67. See Note, supra note 63 , at 675-78.

68. See Donovan, supra note 7 , at 227-29.

69. See Kern \& Ridolfi, supra note 58, at 275-76; Note, supra note 63, at 679

70. Not even all of these activities have been protected. See, e.g., Bowers v. Hardwick, $106 \mathrm{~S}$. Ct. 2841 (1986) (upholding sodomy laws); Michael M. v. Superior Court of Sonoma County, 450 U.S. 464 (1981) (upholding statutory rape laws).

71. Lacey, supra note 63 (arguing that ban on artificial insemination for single women would be unconstitutional). The only state which appears to ban artificial insemination of single women is Oklahoma. See 15 Op. Okla. Att'y Gen. 277 (1983) (interpreting Artificial Insemination Statute, OkLA. Stat. tit. 10, $\S \$ 551-53$ (1981) and Trafficking in Children Statute, OkLA. STAт. tit. 21, $\S$ $866(1981))$. 
medical profession when it limits access to anonymous insemination procedures for unmarried women. ${ }^{\mathbf{2 2}}$ Under conventional constitutional analysis, the unwillingness of doctors to perform artificial insemination on unmarried women would seem no more objectionable (alas) than the unwillingness of some physicians to perform abortions ${ }^{73}$ or some states to fund them. ${ }^{74}$

The constitutional precedent upon which the equal protection presumption for single motherhood-by-choice is based is similarly unpersuasive. While the Supreme Court has held that unmarried women are entitled to some of the same procreative rights as married women, ${ }^{75}$ none of its decisions requires equal treatment of married and unmarried parents. ${ }^{76}$ Likewise, no Supreme Court case has the effect of requiring a state to limit its recognition of parenthood to one parent or the other. Indeed, those cases recognizing a privacy interest of parents in their children have applied to fathers as well as mothers. ${ }^{77}$

72. D'Aversa, The Right of Abortion in Surrogate Motherhood Arrangements, 7 N. ILL. U.L. Rev. 1, 20-26 (1987); Smith \& Iraola, Sexuality, Privacy and the New Biolog;, 67 MARQ. L. REv. 263, 281, 285, 289-91 (1984). But see Note, supra note 63, at 677 (although Supreme Court cases do not address each aspect of procreation process, together they can best be explained as elaborating more general right of privacy with respect to all aspects of procreation).

Catharine Mackinnon has argued that we should not be surprised to find that courts have not defined privacy interests to give much autonomy to women, because the privacy doctrine itself is a tool of male supremacy: "[T] he law of privacy works to translate traditional social values into the rhetoric of individual rights as a means of subordinating those rights to specific social imperatives [footnote omitted] . . . [i.e.] the imperatives of male supremacy." C. MACKinnon, FEminism Unmodified: Discourses ON LifE AND LAW 97 (1987).

73. See Doe v. Bolton, 410 U.S. 179 (1973) (provisions of Georgia statute requiring that physician's decision whether to perform abortion rest upon his best clinical judgment not unconstitutionally vague); see also MD. Health-Gen. Code ANN. \$ 20-214 (a)-(b) (1987) (physicians not required to perform, and hospitals not required to permit abortion, sterilization, or artificial insemination).

Similarly, state requirements that artificial insemination procedures be performed only by doctors would not seem to be unconstitutional, so long as they appear to be a reasonable means of screening donors for genetic defects or infectious diseases. See Curic \& Cohen, supra note 60, at 585-87. Despite the Supreme Court's recognition of the strength of the woman's right to choose an abortion, see Roe v. Wade, 410 U.S. 113 (1973), a number of regulations bearing on that right have been justified as reasonable means of serving important state health objectives; see, e.g., Planned Parenthood v. Ashcroft, 462 U.S. 476, 486-90 (1983) (upholding requirement that fetal tissue be examined by pathologist); Planned Parenthood v. Danforth, 428 U.S. 52, 65-67, 79-81 (1976) (upholding certain consent and record-keeping provisions).

74. See Poelker v. Doe, 432 U.S. 519 (1977) (city's refusal to provide publicly financed hospital services for nontherapeutic abortions while providing such services for childbirth did not deny equal protection).

75. See Eisenstadt v. Baird, 405 U.S. 438 (1972) (right to access to contraception).

76. The Court has made it quite clear that under certain circumstances, it is constitutional to treat unmarried fathers differently from married fathers. See Lehr v. Robertson, 463 U.S. 248 (1983); Quillon v. Walcott, 434 U.S. 246 (1978).

77. Caban v. Mohammed, 441 U.S. 380 (1979) and Stanley v. Illinois, 405 U.S. 645 (1972), for example, both protected the rights of unwed fathers to their children. More recently, Santosky v. Kramer, 455 U.S. 745 (1982), in defining a fundamental liberty interest of "natural parents" in the care, custody, and management of their children, referred to both parents. 


\section{Claims To Extend Constitutional Precedent}

What commentators may mean in asserting the right of unmarried women to become parents with exclusive parental rights is that our law ought to protect women's ability to procreate through artificial insemination and retain autonomy over the children so conceived-in other words, that this right is a reasonable extension of existing legal precedent. The most attractive arguments upon which this normative claim is based stress the values of tolerance, diversity, and private choice; these arguments, however, ultimately fail.

For example, women seeking nonmarital motherhood-by-choice may claim the right to be free from an imposed majority point of view-the view that parenthood is a shared, two-parent enterprise and that it is in the child's best interest to have two parents. This argument ignores the fact that the acceptance of any lifestyle choices on the part of some members of the community is likely to impose an undesirable or offensive point of view on others. If unmarried women prevail on their claims to have unhindered, exclusive nonmarital parenthood, they would be impressing their own view of the community on others. Whether this view is understood to be that nonmarital parenthood is an acceptable social form, or that individuals should be free to choose their own definition of family, it is a moral view that is potentially offensive to those upon whom it is imposed. Neither this position, nor any other, is neutral, nonmoral, or tolerant of all other (competing) moralities.

Another, no more successful, approach is to characterize the activities women seek to protect through their claims for exclusive parenthood as private rather than public, and thus beyond the appropriate reach of state regulation. This argument does not focus on the individual's resistance to the state as the tool of the majority, generally, but rather attempts to locate claims in a zone-the "private" zone-within which the state acknowledges it should not act. This effort is similarly doomed. Others have shown that the private/public dichotomy in family law is illusory: The regulation of, and the failure to regulate, family matters equally reflect public decisions about the family, not all of them benign. ${ }^{78}$

Beyond the analytical difficulties of the rights arguments made on behalf of nonmarital motherhood-by-choice, these claims have ideological consequences that affect the social meaning of parenthood and how people perceive their legal and social obligations. The rights arguments summarized above construct the terms of conflict in ways which emphasize the exclusive interests of disputing owners. As a claim of right, the claim for nonmarital motherhood-by-choice affirms the selfish rather than loving

78. Olsen, The Family and the Market: A Study of Ideology and Legal Reform, 96 HARv. L. REV. 1497 (1983); see also C. MACKinNoN, supra note 72, at 100-02 (public/private distinction is important part of ideology of women's subordination). 
and committed aspect of the parent-child relationship. ${ }^{79}$ Likewise, claims by biological fathers in opposition to mothers' claims draw the battle lines in terms of possession through blood, rather than as a difficult conflict between adults offering relationships to infants to whom they wish to be responsible.

In the next section, I demonstrate how we might proceed to analyze these issues if we want to re-express parenthood to elevate values of responsibility over those of individual right or entitlement.

\section{G. Relationship, Responsibility, and Nonmarital Motherhood-by-Choice}

Fashioning rules to enhance responsibility by adults for their children in response to women's claims of exclusive nonmarital parenthood-bychoice would immediately devolve into disagreement about the definition or meaning of "responsible conduct." Deciding upon a conceptual goal-furthering responsibility within the parent-child relationship-helps set the stage for debate but does little to allay the essential value conflicts underlying questions of parenthood.

The arguments asserted in debate over nonmarital motherhood-bychoice reflect the depth of these value conflicts. On one side, some will argue that it is irresponsible to conceive deliberately and raise children outside a nuclear family; that it is harmful to a child not to have a father; ${ }^{80}$ and, for lesbian mothers who seek exclusive, nonmarital parenthood that it is irresponsible to expose children to a homosexual lifestyle. ${ }^{81}$ On the other side, some will argue that women who wish to bear and raise a child on their own demonstrate a high degree of commitment and responsibility. These women are even more likely to act responsibly, the argument goes, than those who become pregnant without thought, or because social convention congratulates them for doing so. ${ }^{82}$ Moreover, these women seek to act upon an impulse that society both recognizes as necessary to continue the species, and assumes in assigning the job of childrearing to parents. Under this view, impediments to

79. I do not mean to suggest that rights arguments have these negative consequences only when single women use them to assert claims to parenthood. Several feminists have noted that married women who want children are applauded while single women who want children are deemed egoistic. See, e.g., MacIntyre, 'Who Wants Babies?' The Social Construction of Instincts, in Sexual DrviSIONS AND SocietY (D.L. Barker \& S. Allen eds. 1976); Zipper \& Sevenjuijsen, supra note 46, at 131. My point is, rather, that the style of rights arguments tends to promote egoistic instincts among all claimants.

80. See McGuire \& Alexander, Artificial Insemination of Single Women, 43 FERTILITY AND STERILITY 182 (1985) (reporting concern of some physicians, and disputing basis thereof, that lack of father could affect child financially, socially, and cognitively).

81. Id. at 183. Few commentators state this argument directly, though it is implied in much of the literature. See, e.g., Annas, supra note 60, at 5-6 (artificial insemination of lesbian justified only by best interests of adults, not best interests of children). The assumption that homosexuality in parents is bad for children has been made by numerous courts in custody cases. See supra note 56.

82. See Note, supra note 63 , at 680 n.64. 
women seeking exclusive parenthood status weaken the norm of responsibility.

These arguments reflect different values and different assumptions about human nature. Disputes over the "needs" of children are frequently a cover for these unstated assumptions. ${ }^{83}$ The nonmarital motherhood-bychoice debate, in particular, is fueled by numerous studies meant to illustrate the advantages and disadvantages of allowing children to live in single-parent households. ${ }^{84}$ These studies, however, fail to inform the central political question of what kinds of families our society is prepared to allow or encourage.

One fact relevant to this political question is that society already depends heavily upon unmarried women to raise its children. Twenty-two percent of children grow up in single-parent families, ${ }^{85}$ most of which are headed by women. ${ }^{88}$ Women most often get custody of children following divorce. ${ }^{87}$ Even when children live with their fathers in two-parent families, we know that a greatly disproportionate share of child-rearing responsibilities are assumed by women. ${ }^{88}$

These factors may be relevant in different ways. One might argue, for example, that women child-raisers are entitled to the privileges associated with the responsibilities they have assumed. But this is an argument within the exchange view of parenthood; it constructs parenthood in terms of entitlement, based upon acts performed and expectations met.

An alternative view based on the cited data is that parenthood is exercised by single parents, and the state should encourage it to be exercised well. Single parenthood, even if society continues to consider it a secondbest solution, is not per se inadequate or irresponsible. Allowing or recognizing nonmarital motherhood-by-choice, and associating with it the usual expectations we have for parents-a parent's love for her child, her identi-

83. See supra notes $45-46$ and accompanying text.

84. Many of these studies are reviewed in Chambers, supra note 16, at 503-41. Cf. Teitelbaum, Moral Discourse, 84 Mich. L. REv. 430, 437-39 (1985) (research bases for various, and contrary, hypotheses of family law are unreliable).

85. Bureau of the Census, U.S. Dep't of Commerce, Gurrent population Reports, Series P-20, No. 380, Marital Status and Living Arrangements: March 1982 Table E, at 5 (1983).

86. According to U.S. Census figures, about 90 percent of children who live with one parent live with their mothers. Id. at 4.

87. While reliable national figures are not available, Lenore Weitzman found that in the counties she examined in California, well over 80 percent of physical custody awards went to women. $L$. Weitzman, The Divorce Revolution 227-28 (1985).

88. P. Blumstein \& P. Shwartz, American Couples: Money, Work and Sex 144-50 (1983) (reporting 1982 study showing that among couples where both partners are employed fulltime, $18 \%$ of wives do more than 20 hours of housework (including childcare) weekly, as opposed to $4 \%$ of husbands). Figures comparing the extent of responsibility assumed by parents in dual-career families may vary widely, depending in part on who is doing the measuring. In one 1985 study, for example, $57 \%$ of fathers said they were as involved in parenting as the mothers, while only $32 \%$ of independent raters found equal involvement. Thirty-eight percent of fathers rated themselves as less involved than the mothers, while the independent raters set the figure at 54\%. See L. GILBERT, MEN in Dual-Career Families: Current Realities and Future Prospects 74-75 (1985). 
fication with that child, her desire to have that child "turn out well"-reinforce those attributes of parenthood that we want all parents, nonmarital as well as married, to develop. Given how widely experienced single parenthood is, it may seem desirable to affirm, rather than deny or further denigrate, its existence. ${ }^{89}$

Other desirable values may also be transmitted through an acceptance of nonmarital motherhood-by-choice. Nonmarital motherhood-by-choice is, by definition, intentional. Whether we should view responsible parenthood as intentional is, again, a contestable political issue. According to one view, a significant and positive aspect of the parent-child relationship is that it is unpredictable, a matter of spiritual grace to be welcomed if it comes one's way, and thus not an appropriate subject of human control. ${ }^{90}$ Under this view, efforts to control one's procreative activities are wrong and irresponsible. Under the contrary view, planned parenthood is responsible, and unplanned reproduction, especially if one is unable to care properly for one's children, is irresponsible.91 To the extent we mean to promote deliberate choice in parenthood-to endorse family planning as part of parental responsibility-recognition of nonmarital motherhood-bychoice (and perhaps nonmarital fatherhood-by-choice as well) may make sense.

When an unmarried mother's claim for exclusive custody arises in the context of a custody dispute with a father who originally agreed to take no part in the child's parenting, there is the further question whether we should attach any significance to a claimant's previous decision not to assume parental responsibilities. ${ }^{92}$ Should the father be obligated to abide by his initial commitment not to assert parental rights to the child? Whatever we decide, our reasons should be clear. The father should not be disquali-

89. One contrary view is that we should distinguish between unintended single-parent families (brought about by death, divorce, desertion, or unintended out-of-wedlock childbirth) which we can do little to prevent, and intended single-parent families over which we have more control. Since Aristotle, we have assumed that deliberate acts may be more blameworthy, because they could have been prevented, than unintentional acts. See ARistotle, Nicomachean ETrics Book V, ch. 8 (M. Ostwald trans. 1962); sec also H.L.A. HART, supra note 26, at 113-35 (reviewing issues relating to intention and punishment). By the same token, if the law tolerates practices in which people engage deliberately, it is endorsing those practices to a greater extent than it does when it tolerates situations that come about accidentally. I acknowledge this argument, but conclude that the need to dispel the stigma against single parenthood, as well as the benefits of encouraging intentionality in parenthood, see infra text accompanying note 91 , outweigh the values served by discouraging the less favored forms of intentional single parenthood.

90. See K. Luker, Abortion AND the Politics of Motherhood 167-71 (1984) (describing value of unplanned conception to "pro-life" view of world).

91. See generally S. Spicker, W. Bondeson \& H. Engelhardt, JR., The Contraceptive Ethos: RePRodUctive RIGHTS AND RESPONSIBILITIES (1987).

92. This issue echoes a similar one that arises in the context of custody disputes arising from surrogacy arrangements. See infra Part V.

There have been no reported cases involving a woman seeking to establish her claim to nonmarital motherhood-by-choice that neatly raise this issue. In the few custody disputes where it has arisen, the mother was unable to establish convincingly the father's intention not to assume responsibility for the child. See Jhordan C. v. Mary K., 179 Cal. App. 3d 386, 224 Cal. Rptr. 530 (1986) (dispute of fact over terms of arrangement); C.M. v. C.C., 152 N.J. Super. 160, 377 A.2d 821 (1977) (same). 
fied because by his earlier decision he has shown that he does not "deserve" to be a parent. Likewise, if we extend to the father status as parent, it should not be because notwithstanding his intentions he might be held financially responsible for the child and thus should be given reciprocal rights as well; or because his donation of sperm gives him a "right" to the child. These reasons all make parenthood turn on fault, entitlement: exchange.

Instead, our reasons should turn on our assessment of which connections between parent and child are most important to validate. We would like to attach positive value to the biological connection of both parents, but when this is not possible, we may choose to prefer a planned relationship over one that was not only unplanned, but affirmatively unwanted. We may also want to take account of the different degrees of relationship that have been formed. At the time of childbirth, the mother's relationship to her child has developed through pregnancy and childbirth. In contrast, the father's relationship is only a potential one. Affirming the mother's connection to the child (rather than her "rights" or the father's absence thereof) strengthens the importance of relationship to our understanding of parenthood.

The choice of how to state our reasons for recognizing, or declining to recognize, parental claims is a rhetorical move, but nonetheless important. The law's rhetoric defines norms that parties reproduce when they articulate their claims in certain ways. To the extent we may determine that the unmarried woman's decision to have children is a moral one which we should allow her to make, it is important to avoid expressing this freedom as the woman's inviolable "right"; rather, it should be justified as a component of responsible parenthood. If we disapprove of her decision, we should express this disapproval not in terms of the man's "right," but in terms of our intended meaning of parenthood. We might also disapprove of her decision, but not enough to prohibit it. ${ }^{93}$ Then, too, we must be mindful of whether the way we justify this result expresses the values we seek to advance. If parental responsibility is high among those values, the rhetoric of rights is ill-suited to the task.

\section{Unmarried Mothers Choosing to Place Their Ghildren FOR ADOPTION}

Cases in which a biological father objects to a mother's attempt to place the newborn child for adoption also present numerous issues relating to the societal meanings of responsibility within parent-child relationships.

93. Suzanna Sherry suggests this model for state disapproval, without prohibition, of pornography. Sherry, supra note 6 , at 988-89. She notes that this model appears to be the one the United States Supreme Court has adopted with respect to abortion law: A woman has a right to an abortion, but the government may discourage abortions at least to a point, such as by withholding public funding for them. Id. at 989 n.116. 
Both the current legal framework for resolving these cases, and rights claims made to break through that framework, fail to address these issues adequately.

\section{A. The Legal Background}

A father's objection to a woman's attempt to relinquish their child to a third-party couple for adoption generates conflicting impulses within the law. On the one hand, giving the unwed father the full range of parental rights when the unwed mother decides to give up her rights seems only fair to the father, and serves the goal of assuring the child at least one "natural" parent. On the other hand, a newborn who is adopted into a two-parent nuclear family is presumed to have advantages over a child raised by a single parent. ${ }^{94}$ State laws reflect this tension. Generally speaking, when the unmarried mother gives up her child for adoption, the biological father who meets the specified statutory criteria becomes the mother's substitute, with the power to stop the adoption and take custody of the child himself. ${ }^{95}$ The mother's action in placing the child for adoption constitutes, in effect, a forfeiture of her otherwise superior rights. If she chooses not to exercise those rights by retaining custody of the child, the father's rights take over. ${ }^{98}$

The statutory criteria that unmarried fathers must meet, however, may be quite rigorous, facilitating the ability of the unmarried mother to place her child for adoption. Applied strictly, these criteria in some instances may have the effect of treating a decision by the mother to place her child for adoption as an exercise of her (superior) parental rights rather than as

94. Shoecraft v. Catholic Social Serv. Bureau, 222 Neb. 574, 385 N.W.2d 448, 452 (1986) (citing public policy in favor of adoption of children born out of wedlock as soon as possible after birth, and stability of normal, two-parent home), appeal dismissed as moot, 479 U.S. 805 (1986); In re Joseph L.L., 97 A.D.2d 263, 470 N.Y.S.2d 784, 786 (1983) (in upholding statute eliminating need for consent to adoption by natural parent who has been imprisoned, court discusses state legitimate interest in providing child with stability of normal two-parent home); In re Adoption of Baby Boy D., 742 P.2d 1059, 1068 (Okla. 1985) (best interests of child born to unmarried parents is adoption); Caban v. Mohammed, 441 U.S. 380, 391 (1979) ("We do not question that the best interests of . . . [illegitimate] children often may require their adoption into new families who will give them the stability of a normal, two-parent home."). For a different statement of this dilemma, see Buchanan, The Constitutional Rights of Unwed Fathers Before and After Lehr v. Robertson, 45 OH1O ST. L.J. 313, 314-15 (1984) (adoption has double effect on parental interests, by both establishing one set of parental relationships and terminating another).

95. See, e.g., ArIz. Rev. Stat. ANN. § 8-106(A)(1) (1974 \& Supp. 1986); Cal. Civ. Code § 224 (West 1982); IND. Code ANN. $\S 31-3-1-6$ (Burns 1987); MD. FAM. Law Code ANN. §§ 5-311 to -312 (1984); Mich. Comp. Laws AnN. $§ 710.31$ (West Supp. 1988); N.C. Gen. Stat. § 48-7 (1987).

96. See Adoption of Baby Boy D., 159 Cal. App. 3d 8, 23, 205 Cal. Rptr. 361, 369 (1984) ("So long as [the mother] does not assert [her] right to physical custody, [the father] may not be denied custody of his child or have his parental rights terminated except upon a finding that leaving custody with [the adoptive parents] is necessary to avert harm to the child."); In re Baby Boy Barlow, 404 Mich. 216, 273 N.W.2d 35 (1978) (if unwed mother releases child for adoption, father's parent-child relationship may be terminated only if it is shown that to do so would be in child's best interests); In re Mitchell, 70 A.D.2d 367, 421 N.Y.S.2d 443 (1979) (unwed father entitled to custody if mother releases child for adoption and if there is no showing that father is unfit). 
a forfeiture of them. For example, a number of state statutes make the consent of an unwed father unnecessary to the child's adoption if the father has not formally acknowledged his paternity, ${ }^{97}$ had his paternity judicially established, ${ }^{98}$ or provided substantial financial support or consistent care to the child. ${ }^{98}$ Some states have very limited notice provisions, ${ }^{100}$ or require no notice to fathers at all under certain circumstances. ${ }^{101}$ Where consent is required, the father's parental rights may be overcome in some states under standards more lenient than those that apply in other custody contexts. ${ }^{102}$ These rules reflect a concern for the mother to be able to

97. See, e.g., ARK. STAT. ANN. \$ 9-9-206 (1987) (natural father's consent to adoption required only if he is (or was) married to mother, or if he has custody, or if he has legitimated the child), upheld in In re S.J.B., 745 S.W.2d 606 (Ark. 1988); FLA. STAT. ANN. \$§ 63.062, 63.072(1) (West 1986) (natural father's consent not necessary where he has not filed acknowledgement of paternity), interpreted in Wylie v. Botos, 416 So. 2d 1253 (Fla. Dist. Ct. App. 1982); Urah Cone ANN. § 7830-4(3) (1987) (unwed father's parental rights may be terminated without his consent if he fails to file notice of paternity prior to filing of petition for adoption), interpreted in In re Baby Boy Doe, 717 P.2d 686 (Utah 1986); see also NEB. REv. STAT. \$ 43-104.02 (1984) (unwed father has no parental rights unless he files notice of intent to claim paternity within five days after child's birth), interpreted in Shoecraft v. Catholic Social Serv. Bureau, 222 Neb. 574, 385 N.W.2d 448 (1986); OR. REV. STAT. \$ 109.096(3) (1984) (unwed father barred from contesting adoption proceeding if he does not file notice of initiation of filiation proceedings before placement for adoption), interpreted in G.S.B. v. S.M.D., 720 P.2d 1339 (Or. Ct. App. 1986).

98. See, e.g., IND. CODE ANN. $\S 31-3-1-6(\mathrm{~g})(2)(\mathrm{A})$ (Burns 1980) (natural father's consent not necessary where his paternity has not been judicially established), interpreted in M.R. v. Meltzer, 487 N.E.2d 836 (Ind. Ct. App. 1986).

99. See, e.g., N.J. STAт. ANN. \$§ 9.3-46 (West Supp. 1988) (unwed father may object to adoption if he acknowledges child, unless court finds substantial failure to perform regular and expected parental functions of care and support, including maintenance of emotional relationship); N.Y. DoM. REL. LAw $\S 111$ (McKinney 1986) (if a child is less than six months old, father must have lived openly with mother or child, held himself out as father, and paid reasonable medical expenses of pregnancy; if child is older than six months, father must have had substantial and repeated contacts with child, including support, regular visitation or communication); OHio REv. CODE ANN. §§ 3107.06-.07 (Anderson Supp. 1987) (putative father cannot object to adoption if he has abandoned mother during her pregnancy and up to time of surrender, or has wilfully abandoned or failed to care for and support child).

100. See, e.g., DEL. Code ANN. tit. 13, $\S 11105,1106,1113$ (1981) (if mother refuses to disclose name of unwed father, court may terminate father's parental rights without notice to him in order to enable child to be adopted more readily), interpreted in In re Karen A.B., 513 A.2d 770 (Del. 1986); VA. CODE ANN. \$63.1-225 (1987) (unwed father's consent not required if his identity is not "reasonably ascertainable" or if father is given notice but fails to object to adoption within 21 days; unrefuted affidavit of mother stating that identity not reasonably ascertainable sufficient), interpreted in Augusta County Dep't of Social Servs. v. Unnamed Mother, 348 S.E.2d 26 (Va. Ct. App. 1986) (publication notice sufficient to meet requirement of statute).

101. See, e.g., Lehr v. Robertson, 463 U.S. 248 (1983) (upholding N.Y. DoM. REL. Law § 111a(2)(a)-(h) (McKinney 1988), which requires notice of adoption proceedings to putative fathers in number of circumstances, but not where putative father has filed paternity action that has not been resolved but of which mother and state have notice); see also In re Karen A.B., 513 A.2d 770 (Del. 1986) (no notice to putative father in third-party adoption proceeding, where mother refused to disclose his name and testified that he would be unable to care for child); infra note 114 .

102. Thus, although the United States Supreme Court indicated that the rights of a father who is, or was, married to the child's mother ordinarily cannot be terminated without a showing of unfitness, the Court upheld the constitutionality of a Georgia statute which provided that the rights of a father who had not legitimated his child could be cut off through adoption, and that legitimation could be denied on the basis of the best interests of the child standard. Quilloin v. Walcott, 434 U.S. 246, 255 (1978), citing Smith v. Org. of Foster Families, 431 U.S. 816, 862-63 (1977) (Stewart, J., concurring); see also N.Y. DoM. REL. LAW $\S 111$-a(3) (McKinney 1988) (limiting participation of unwed fathers in adoption hearings to presenting information and arguments about child's best interests); TEX. FAM. CoDE ANN. $\S \S 11.01(3), 12.02(c), 13.21$ (Vernon 1986) (allowing legitimation petition of 
make a decision about adoption as quickly as possible for the benefit of the child, with the knowledge that the father will be unable to thwart her plan. ${ }^{103}$

It is clear from the Supreme Court's opinion in Caban v. Mohammed, ${ }^{104}$ that a father who has actually assumed significant responsibility toward his child or developed a meaningful parent-child relationship has parental rights which may not be abrogated simply at the will of the mother. ${ }^{105}$ What is less clear is whether the father must be given the opportunity to establish such a relationship. Some courts have decided that he must; ${ }^{108}$ others have disagreed. ${ }^{107}$ In Lehr $v$. Robertson, the United States Supreme Court stated that "[ $t$ ] nection is that it offers the natural father an opportunity that no other

unwed father to be denied under best interests standard), upheld in In re T.E.T., 603 S.W.2d 793 (Tex. 1980), cert. denied, 450 U.S. 1025 (1981).

103. See, e.g., Shoecraft v. Catholic Sacial Serv. Bureau, 222 Neb. 574, 579, 385 N.W.2d 448, 452 (1986) (warning against leaving mother "in the terrible limbo of growing attachment and love for the child, awaiting either the outcome of a judicial proceeding with its attendant notoriety or the decision of the amorous Hamlet in the wings, pondering whether he should assume his responsibility.").

104. 441 U.S. 380 (1979) (holding that parental rights of father who had established significant relationship with his children were constitutionally protected and could not be terminated by stepfather's adoption of child).

105. See Lehr v. Robertson, 463 U.S. 248, 261 (1983) ("When an unwed father demonstrates a full commitment to the responsibilities of parenthood by 'coming forward to participate in the rearing of his child,' Caban v. Mohammed, 441 U.S. at 392, his interest in personal contact with his child acquires substantial protection under the Due Process Clause.").

Those cases that deny a father the right to block an adoption frequently note the failure of the father to care for the child and mother. See, e.g., In re Marie R., 79 Cal. App. 3d 624, 145 Cal. Rptr. 122,123 (1978) (despite efforts to do so, putative father had never seen baby, and had not contributed to baby's or mother's expenses); In re Steve B.D., 112 Idaho 22, 730 P.2d 942 (1986) (father did not pay medical expenses related to birth or any expenses related to child's support, and refused request to sign paternity affidavit); Shoecraft v. Catholic Social Serv. Bureau, 222 Neb. at 576, 385 N.W.2d at 450 (father did not pay expenses connected with residence of mother before birth or costs of hospital and physician connected with child's birth, and did not complete medical questionnaires sent to him); In re Adoption of Baby Boy D., 742 P.2d 1059, 1068 (Okla. 1985) (father did not contact mother during her pregnancy, and did not offer financial support). See also supra note 99 and infra note 139.

In California, the rules determining who must consent to an adoption directly incorporate the sorts of factors that have been given constitutional recognition. California distinguishes between a "presumed" father and a "natural" father. A presumed father is a natural father who has married or attempted to marry the child's mother within a certain time period, or who has received the child into his home and openly held out the child as his natural child. CAL. Crv. CoDE $\S 7004$ (West 1983). Only the consent of a presumed father is necessary in order for his child to be adopted, CaL. Civ. CODE $\S 224$ (West 1982); the consent of a natural father who is not a presumed father is not required. California law requires, however, that a natural father be notified of an adoption proceeding in order to ensure that he is given the opportunity to prove that he is a presumed father. CAL. CIV. CODE $\$ \S 7017$ (c) \& (d) (West 1983 \& Supp. 1987). For cases interpreting these rules, see infra note 115.

106. See, e.g., Adoption of Baby Boy D., 159 Cal. App. 3d 8, 205 Cal. Rptr. 361 (1984) (discussed infra note 115); Matter of Baby Girl Eason, 257 Ga. 292, 358 S.E.2d 459 (1987).

107. See cases discussed infra notes 111-116. In those states in which notice to a known father is not required, see supra notes $100-01$, it is unclear how a father would be able to raise the issue of what responsibilities he had assumed toward the child. Without stating so, courts may assume that if a mother is able to slip an adoption proceeding by the husband unnoticed, he has probably not established a relationship to the child of sufficient strength to warrant special constitutional protection. 
male possesses to develop a relationship with his offspring." 108 Yet in Lehr, the Court found that the state was not constitutionally required to give the father notice and an opportunity to be present at the adoption proceedings, even though he tried to establish a link with the child (including offering to support the mother during and after her pregnancy, and attempting to visit the child); his inability to take on responsibility for the child was due not to his inaction, but to the mother's lack of cooperation. ${ }^{109}$

The Court in Lehr was undoubtedly influenced by the fact that for five years, the child had lived with the stepfather, who wished to adopt the child. ${ }^{110}$ A number of lower courts, however, have declined to recognize that the father has a constitutional right to notification, even in the context of adoption by third parties. In one such case, the Idaho Supreme Court held that although the state may not deprive the father of the opportunity to assert his interest in the child, the mother herself may do so. ${ }^{111}$ An adoption is not defective just because the mother has concealed the child from the father and prevented him from developing a relationship with that child. ${ }^{112}$ The Texas Supreme Court also has concluded that an unwed father who repeatedly attempts to establish a relationship with his infant might, nevertheless, have no parental rights if the mother succeeds in denying him access. ${ }^{113}$ Courts in Arkansas and Oregon have followed suit, ${ }^{114}$ while courts in California ${ }^{115}$ and Utah ${ }^{116}$ have shifted back and forth on the issue.

108. 463 U.S. 248,262 (1983).

109. Id. at 268-76 (White, J., dissenting). The father could have filed a notice of his paternity in the putative father registry, but failed to do so, perhaps because he uas unaware of the alternative. Id. at 262 .

110. Id. at $262 \mathrm{n} .19$. See Buchanan, supra note 94, at 371-81 (suggesting that opportunity interest of biological father in adoption by strangers case should be greater than his opportunity interest in stepparent adoption case).

111. In re Steve B.D., 112 Idaho 22, 25, 730 P.2d 942, 945 (1986) ("The Reeting opportunity may pass ungrasped through no fault of the unwed father or perhaps due to the interference of some private third party; nevertheless, once passed the unwed father is left without an interest cognizable under the Fourteenth Amendment." (citation omitted)).

112. In re Steve B.D., 112 Idaho 22, 730 P.2d 942 (1986). This case followed an unsuccessful attempt by the mother of the child to revoke her consent to the adoption. See In re Steve B.D., 111 Idaho 285, 723 P.2d 829 (1986). The mother and the father subsequently declared a common law marriage, but by then, the child had been with the adoptive parents for more than two years. Id. at 290-92, 723 P.2d at 834-36.

The lack of involvement of the state in preventing the biological father from developing a relationship with the child was also a factor noted by the California Supreme Court in upholding a state statute that denied standing to a putative father to attack the presumption of legitimacy. See Michelle W. v. Ronald W., 39 Cal. 3d 354, 362, 216 Cal. Rptr. 748, 752, 703 P.2d 88, 92, (1985), appeal dismissed sub nom. Michelle W. v. Riley, 106 S. Ct. 774 (1986).

113. In re T. E. T., 603 S.W.2d 793 (Tex. 1980), cert. denied, 450 U.S. 1025 (1981).

114. See In re S.J.B., 14 Fam. L. Rep. (BNA) 1223 (Ark. 1988) (upholding ARK. STaT. ANN. §§ 9-9-206(a)(2) \& 9-9-207(a)(3) (1987) which permit adoption by third-party strangers without notice to unwed father who did not have custody of child, marry child's mother or legitimate child, where father was unaware of child's birth); G.S.B. v. S.M.D., 720 P.2d 1339 (Or. Ct. App. 1986) (applying OR. REv. STAT. $\$ 109.096(3)$ (1987), which cuts off rights of putative father without notice if he does not file filiation proceeding before child is placed in adoptive home). 


\section{B. Rights Claims}

Women seeking to overcome rules giving unwed fathers veto power over adoptions, or to defend rules that allow them to make the adoption decision without interference. by the father, make rights claims that, again, start with the proposition that the woman's right to place her child for adoption is compelled by her privacy interest in deciding " whether to bear or beget a child"."117 The argument is sometimes bolstered by the claim that "since the mother had the absolute right to decide to abort and

115. In In re Tricia M., 74 Cal. App. 3d 125, 141 Cal. Rptr. 554 (1977), the California Caurt of Appeals held that an unwed father must be given the opportunity to develop a relationship with his child before the child could be placed for adoption based only on the consent of the mother. In Adoption of Marie R., 79 Cal. App. 3d 624, 630, 145 Cal. Rptr. 122, 126 (1978), however, the Court of Appeals allowed a third-party adoption notwithstanding the father's objection that the child's mother had prevented him from developing a relationship with the child; the court held that the mother's conduct in frustrating the father's efforts to establish contact was an insufficient reason to deny the adoption. Then, in W.E.J. v. Superior Court, 100 Cal. App. 3d 303, 310-11, 160 Cal. Rptr. 862, 866-67 (1979), approving Marie $R$. and questioning the "unwarranted" advice given by the Tricia $M$. court, the Court of Appeals held that the father need not be given the opportunity to establish a relationship that the mother had refused to allow to develop. Still another shift occurred in Adoption of Baby Boy D., 159 Cal. App. 3d 8, 205 Cal. Rptr. 361 (1984), when the Court of Appeals held that a father's rights to due process of law mandated the application of the parental preference doctrine. So long as the mother did not assert her right to custody, the court stated, the biological father could not be denied custody or have his parental rights terminated except on a finding that leaving custody with the adoptive parents was necessary to prevent harm to the child. $159 \mathrm{Cal}$. App. $3 \mathrm{~d}$ at 22, $205 \mathrm{Cal}$. Rptr. at 369.

California's Supreme Court has done nothing to clarify the issue. In In re Baby Girl M., 37 Cal.3d 65, 207 Cal. Rptr. 309, 688 P.2d 918 (1984), the state Supreme Court appeared to assume that an opportunity should be given to a natural father to establish a relationship with his child and thus become a presumed father, entitled to block an adoption. In that case, a mother attempted to place for adoption her child born out of wedlock without informing the natural father or allowing him to assume responsibility for the child. The Court focused not on the question of what opportunity the father must be given to develop a relationship with his child, but on whether a finding of detriment was required under CAL. Crv. Code $\$ 4600$ (West 1983) before a child could be placed with an adoptive rather than a natural parent. After the lower court, on remand, made the necessary finding of detriment, see In re Baby Girl M., 191 Cal. App. 3d 786, 236 Cal. Rptr. 660 (1987), the United State Supreme Court granted review on the question of whether the equal protection rights of an unwed father who manifested significant parental interest in his child are violated when his rights are terminated upon a finding of detriment. McNamara v. San Diego County Dep't of Social Serv., 108 S. Ct. 1466 (1988); see also Michael U. v. Jamie B., 39 Cal. 3d 787, 218 Cal. Rptr. 39, 705 P.2d 362 (1985) (holding no substantial evidence to support trial court's decision that placement with natural father would not be detrimental to child).

116. UTAH CODE ANN. § 78-30-4(3)(b) (1987) permits termination of the parental rights of the father of an illcgitimate child if the father fails to file a notice of paternity prior to the filing of a petition for adoption. Cases interpreting this statute have varied on the level of opportunity a father must be given to comply. Compare Ellis v. Social Servs. Dep't of the Church of Jesus Christ of Latter-Day Saints, 615 P.2d 1250 (Utah 1980) (due process requires father who was out of state at time child was born to be given opportunity to show that he was not afforded reasonable opportunity to comply with statute) and In re Adoption of Baby Boy Doe, 717 P.2d 686 (Utah 1986) (due process offended where father expected mother to bring child to live with him and father not contacted by mother about birth of child until after child relinquished for adoption) with Wells v. Children's Aid Soc'y, 681 P.2d 199 (Utah 1984) (due process satisfied where mother did not know father opposed adoption and where father had notice of birth and of mother's intent to relinquish child for adoption) and Sanchez v. L.D.S. Social Servs., 680 F.2d 753 (Utah 1984) (due process does not require that father have notice of statute).

117. Erickson, The Feminist Dilemma Over Unwed Parents' Custody Rights: The Mother's Rights Must Take Priority, 2 LAw \& INEQUALITy 447, 456 (1984) (quoting Eisenstadt v. Baird, 405 U.S. 438,453 (1972)). 
[instead] decided to allow her body to be used to bear the child, she should have priority for custody."118

Both of these arguments fail to address the conflicting rights of the father. The Supreme Court has recognized the male, as well as the female, right to procreate. ${ }^{110}$ Supreme Court precedent establishing the constitutional rights of parents to their children also has covered men as well as women. ${ }^{120}$

In defending the mother's rights to give up her child for adoption, Professor Nancy Erickson argues that the father's constitutional rights depend upon the existence of a family that, in the case of unwed biological parents who are not living together, does not and will never exist. ${ }^{121}$ This argument misreads the significance the Supreme Court has attached to the relationship between a child and his or her unmarried father. Although the cases Erickson cites, Quilloin v. Walcott ${ }^{122}$ and Stanley v. Illinois, ${ }^{123}$ distinguish situations where an ongoing family relationship existed (Stanley - father's rights protected) from those where one did not (Quilloin-father's rights not protected), neither case endorses or permits the destruction of one parent-child relationship (inchoate or otherwise) on behalf of another parent-child relationship that does not yet exist (i.e., the adoptive family). Likewise, neither permits one parent to terminate the interests of the other in order that the first may turn his or her rights over to a third party. Again, further justification is required.

One possible justification, offered by Erickson, is that since the woman has endured the risks, inconvenience, and pain of pregnancy and childbirth, she deserves to have all of the rights associated with the child. ${ }^{124}$ This claim is one of ownership, explicitly focusing on what is fair to a person who has performed certain feats or experienced certain deprivations. The argument implicitly undermines affirmative parental attitudes of giving, responsibility, and commitment, by rendering them objects of exchange. In the following section, I restructure the issues to redeem those values.

\section{G. Relationship, Responsibility, and Adoption of Newborns}

In analyzing how we might attempt to implement the norm of responsibility in parent-child relationships, we confront two overlapping tensions. First, the goal of promoting the ideology of parental responsibility as a general matter may conflict with the goal of making evaluations based

118. Id. at 451.

119. See Skinner v. Oklahoma, 316 U.S. 535 (1942) (protecting man's right not to be involuntarily sterilized).

120. See supra note 77.

121. Erickson, supra note 117 , at 457.

122. 434 U.S. 246 (1978).

123. 405 U.S. 645 (1972).

124. Erickson, supra note 117, at 466. 
upon that ideology in individual cases. Second, the goal of protecting and enhancing the norm of responsibility within the mother-child relationship may interfere with the goal of protecting and enhancing responsibility within the father-child relationship.

The tension in the law between expressing desirable values in our general rules and reaching the "correct" results in individual cases is a recurring dilemma. Simple rules with few or no exceptions, such as those that give automatic authority to fathers to block adoptions, may send the most unequivocal messages-such as that fathers are responsible for children. The stronger the rules that both parents have responsibility, the more reinforced will be the norm that both parents should assume responsibility (reinforcement we may badly need ${ }^{125}$ ). Yet where the result of applying such a rule in a particular situation is to allow an irresponsible father to thwart the responsible plans of a mother to provide for the care of their child, the rule seems to bring the wrong result and, in rewarding irresponsibility, send the wrong message.

The tension between promoting responsibility by fathers and promoting responsibility by mothers further complicates the matter. A rule that recognizes the biological connection between father and child by giving unwed fathers veto power over adoptions will promote, in a general way, the ideology that biological fathers should, and will, love and care for their children and be responsible parents. As a result, we might expect fathers actually to care more for their children and to provide them with material and emotional support.

Quite the opposite rule, however-one that recognizes the mother-child relationship by giving the mother authority to place the child for adoption-will support maternal responsibility. While this goal already has considerable support in our social and legal ideologies, there may be special reasons to emphasize its importance. Mothers have a kind of automatic responsibility for their children. ${ }^{28}$ Under current law the mother may decide whether to abort the fetus. ${ }^{127}$ And she must decide how to conduct herself and care for herself and the child during pregnancy. ${ }^{128}$ These decisions, including whether she smokes, drinks, or keeps

125. Bartlett \& Stack, supra note 5, at 33-34.

126. See In re Adoption of Baby Boy D., 742 P.2d 1059, 1068-69 (Okla. 1985) (from time of birth, mother more likely than father to be faced with decisions about how to best care for child); In re T.E.T., 603 S.W.2d 793, 797 (Tex. 1980), cert. denied, 450 U.S. 1025 (1980) (mother automatically responsible for child in way that father is not); In re Baby Girl S., 628 S.W.2d 261, 264 (Tex. Civ. App. 1982), vacated sub nom. Kirkpatrick v. Christian Homes of Abilene, Inc, 460 U.S. 1074 (1983) (same).

127. Roe v. Wade, 410 U.S. 113 (1973).

128. In some states, the pregnant woman may be subject to criminal penalties for failing to care adequately for her fetus. For a discussion of a woman's legal duties during her pregnancy, compare Stearns, Maternal Duties During Pregnancy: Toward a Conceptual Framework, 21 NEw ENG. L. REv. 595 (1985-86) with Meyers, Abuse and Neglect of the Unborn: Can the State Intervene?, 23 DuQ. L. REv. 1 (1984) (condemning imposition of prenatal duties prior to fetus' viability); Note, Maternal Rights and Fetal Wrongs: The Case Against the Criminalization of "Fetal Abuse," 101 
a healthy diet, are extremely important to the child. ${ }^{128}$ After childbirth, too, it is almost inconceivable to us that the mother will have no part in deciding what will happen to the child. Rules that give unmarried mothers the authority to make decisions about their children, including whether to place them for adoption, "[encourage] the unwed mother to properly care for the child by assuring her that her wishes as to the disposition of the child will not, absent her consent or a finding of the child's best interest, be subject to the absolute veto of the biological father."130

We instinctively want to transform this responsibility point into a rights or entitlement argument. Because the pregnant woman cannot avoid taking responsibility for the child, the argument would go, it is only fair to allow her to place her child for adoption. ${ }^{131}$ This form of argument, however, reflects the exchange view of parenthood, which in turn elevates parental rights over parental responsibility. To promote responsibility, we must focus instead on the links between responsibility, the need for freedom to act, and the circumstances under which parents will exercise this freedom.

There is an enormous range of circumstances within which conflicts over placement of children for adoption occur. The mother may wish to place the child for adoption because her economic circumstances and her family support networks make her unprepared or unable to provide properly for the child; she may conclude that although she longs to keep her child, the child would be better off with an adoptive family. ${ }^{132}$ In these circumstances, her decision to place her child for adoption is an act of selfsacrifice for the welfare of her child. If she is not permitted to carry out her plan, she may decide to keep the child herself, ${ }^{133}$ or to abort the

HARv. L. REv. 994 (1988) (arguing that criminalization of fetal abuse violates woman's constitutional privacy interests); Recent Developments, The Pamela Roe Stewart Case and Fetal Harm: Prosecution or Prevention?, 11 HARv. WomeN's L.J. 227 (1988) (arguing against fetal harm statutes). In the most highly publicized case on this subject to date, involving a pregnant woman who abused drugs and failed to follow her doctor's orders, a demurrer was sustained to charges brought under a criminal non-support statute. People v. Stewart (San Diego Mun. Ct. Feb. 26, 1987) (No. M508 197) (copy on file with author).

129. The pregnant woman's peace of mind, which may be affected by whether she will be able to make binding decisions on behalf of the child, may also be important to the health of the child she is carrying. Erickson, supra note 117 , at 460 .

130. In re T.E.T., 603 S.W.2d at 797; see also In re Adoption of Baby Boy D., 742 P.2d at 1068-69 (because from conception through infancy unwed mother will constantly be faced with decisions about how to care for child not faced by unwed father, mother must be given maximum flexibility to decide how best to care for child); In re Baby Girl S., 628 S.W.2d at 264.

131. See, e.g., In re Baby Girl S., 628 S.W.2d at 264; see also In re Adoption of Baby Boy D., 742 P.2d at 1069; In re T.E.T., 603 S.W.2d at 797.

This argument would be weaker where the mother was married and her husband had automatic legal responsibility for the child. See Quilloin v. Walcott, 434 U.S. 246, 256 (1978); Buchanan, supra note 94, at 336, 340; Hafen, supra note 9, at 496, 498.

132. See, e.g., Adoption of Baby Boy D., 159 Cal. App. 3d 8, 205 Cal. Rptr. 361 (1984).

133. See, e.g., id., 205 Cal. Rptr. at 369; Michael U. v. Jamie B., 39 Cal.3d 787, 793 n.5, 705 P.2d 362, 43 n.5, 218 Cal. Rptr. 39, 43 n.5 (1985); In re Anonymous, 97 Misc.2d 927, 416 N.Y.S.2d 729 (1979); see also Erickson, supra note 117, at 458-59. Professor Erickson obtained statements from unwed mothers who explained their decisions to place their newborns for adoption, as part of 
child. ${ }^{134}$ Either of these two alternatives would be a choice that she might consider inferior to adoption, but necessary in her view to prevent what she perceives as an even greater harm-custody of the child by an irresponsible father.

Not all mothers, however, make decisions based on their consideration of the welfare of the child. It is conceivable that a mother may want to give up her child casually, because she concludes that having a child would interfere with her life. She may intentionally wish to frustrate the father's interest in having a child, without regard to how adequate a parent he (or she) might be. Or she may wish, simply, to act on a strongly held principle (or "right") that she, and not the father, is entitled to make the choice, because she has taken all of the mental and physical risks of pregnancy and childbirth ${ }^{135}$ (an attitude fostered, I have argued, by the legitimation of rights arguments).

The range of circumstances within which fathers act may also be quite varied. ${ }^{138}$ Some fathers will feel a strong psychological attachment to their children and wish to do well by them. These fathers will make sure that they have enough economic resources and family support to be able to do so. Others will react primarily to a possessive urge to control someone they perceive as being "theirs," 137 or want to keep the child as an act of power over the child's mother.

In the face of the wide range of possible factual scenarios, a simple, automatic rule that assumes one particular set of circumstances-for example, that mothers always act to best promote the welfare of their children ${ }^{138}$ - may reinforce certain desirable aspects of responsibility in some cases, but lead to very unsatisfactory results in others where the circumstances do not match the rule. This dilemma suggests the need for broad rules with specific, individualized application. Such rules should create a responsibility-based standard that both assumes, and attempts to measure, responsible decision-making in individual, highly fact-dependent cases in which parents make competing claims to a newborn. The relevant factors may include a parent's reason for relinquishing a child for adoption (or

her work for an amicus brief to the United States Supreme Court in support of the constitutionality of TEx. FAM. CoDE ANN. $\S \S 11.01(3), 12.02(c), 13.21$ (Vernon 1986), under which an unwed father may be able to legitimate his child and thus to block an adoption only if the mother agrees or the court finds legitimation to be in the child's best interests.

134. Erickson, supra note 117 , at $455,460$.

135. Id. at 466 .

136. See In re K., 535 S.W.2d 168, 171 (Tex. 1976), cert. denied, 429 U.S. 907 (1976) (need to distinguish father who is devoted to child, from rapist, sperm donor, or man who has engaged in "hit and run sexual adventure").

137. See, e.g., Adoption of Baby Boy D., 159 Cal. App. 3d at 16, 205 Cal. Rptr. at 364 (quoting unwed father attempting to block adoption: "Well, I don't really care anyway. I just want to prove my point, and I would probably give the baby back to the [adoptive parents] anyway.").

138. Cf. Hafen, supra note 9, at 496-501 (urging, in unwed father cases, that law assume unmarried father will not have long-term commitment to his child that married father will have). 
opposing the adoption), the plan for the child, the nature of the relationship already established with the child, and so on.

Such an approach could well incorporate shorthand devices, such as presumptions or burdens of proof, that interpret society's current understanding of what constitutes responsibility, and that avoid some of the uncertainty and cost of individualized hearings. Thus, for example, the law might begin with a presumption that the mother's actual relationship to the child established during pregnancy and childbirth makes her decision to place the child for adoption a responsible one, a presumption which the father may overcome with evidence that his plan to keep the child is more responsible. Convincing and realistic plans for providing adequately for the child would be relevant evidence, as would evidence about his attitude toward the mother's pregnancy. ${ }^{\mathbf{1 3 9}}$

Rules requiring the father to take affirmative steps to give notice of or judicially establish his paternity in order to have any rights in the adoption proceeding ${ }^{140}$ might also be justified. These rules, however, should be based upon society's understanding of relationship and responsibility, rather than on what seems fair to the parents. Results should depend ultimately upon societal judgments about existing and potential opportunities for responsible parent-child relationships, rather than upon what is due parents. Thus, for example, rules should permit distinctions between fathers who demonstrate responsibility and those who simply wish to frustrate the mother's wishes to place the child for adoption or to have what is "theirs."

An individualized, fact-specific approach may grant considerable discretion to judges. It has become routine to criticize judicial discretion on the grounds that it makes decisions too subjective and unpredictable. ${ }^{141}$ However, certainty or predictability of results can be overrated. Simple, easily administrable rules, while generally desirable, almost necessarily have the effect in custody cases of disregarding, even denying, the significance of the quality of parental behavior or attention to the parent-child relationship in individual cases. ${ }^{\mathbf{1 2}}$ An approach that avoids questions about re-

139. See, e.g., Adoption of Baby Boy D., 159 Cal. App. 3d 8, 205 Cal. Rptr. 361 (1984) (father initially refused financial responsibility of pregnancy, and at one time suggested mother have abortion); In re Adoption of Doe, 524 So. 2d 1037 (Fla. App. 1988) (father urged mother to have abortion, was erratic in his support of her during pregnancy, and kept changing his mind about child's adoption); In re Adoption of Baby Boy D., 742 P.2d 1059 (Okla. 1987) (father showed no interest in mother's pregnancy); In re K., 535 S.W.2d 168 (Tex. 1976), cert. denied, 429 U.S. 907 (1976) (same); see also cases cited supra note 105.

140. See supra notes 97-98 and accompanying text.

141. See, e.g., Mnookin, supra note 13; see also Elster, supra note 16, at 24 (simple, automatic rules lead to fewer and shorter custody disputes); Hafen, supra note 9, at 484, 500, 515-16, 559 (rule of law threatened if individualized, subjective determinations required).

142. Cf. Mnookin, supra note 13, at 290 (decisionmaking by coin-flip "symbolically abdicates government responsibility for the child and symbolically denies the importance of human differences and distinctiveness."); Schneider, Mcral Discourse, supra note 9, at 1860 (treating people as individuals allows law to make more complex and therefore fuller moral judgments about them and their 
sponsible conduct declares that the nuanced values we may wish to advance are not important enough to warrant the bother of difficult factfinding.

Individualized hearings, by contrast, allow parents to argue about the content and meaning of their own relationships with the child and what they think matters in these relationships. In articulating their hoped-for roles with respect to the child, parents will be participating in the creation of their own meanings and further public meanings of responsibility in parenthood. As more of these discussions take place, our understanding of what should matter will evolve and, hopefully, improve. While this process may lack the simplicity and administrability we prefer, it appropriately reflects the complex values and tensions that questions about parenthood entail.

\section{Surrogate Mothers Choosing to Keep Their Ghildren}

Infertile couples ${ }^{143}$ sometimes resort to surrogate mother ${ }^{144}$ arrangements in order to produce a child biologically related to one of them. Conception is accomplished, ordinarily, through the artificial insemination of a "surrogate" who accepts money in return for her agreement to surrender the child to the father and to have her parental rights immediately terminated. If a surrogate mother changes her mind and wants to keep her child, she may seek to exclude the biological father entirely from the child's life. In this event, her claim to keep the child will violate not only the terms of her contract, but also custody rules designed to insure that a child have two parents. ${ }^{145}$ The custody battle between biological parents that follows sets at odds some of our most basic values-the sanctity of

situations).

143. Most commentators assume that the contracting couple will be infertile, but there may be other reasons why couples seek surrogacy, such as the desire to avoid transmitting genetic defects or the inconvenience and risk of pregnancy. See infre note 187 . These other factors complicate considerably the policy analysis of surrogacy contracts.

144. Despite its misleading connotations, I use the term "surrogate mother" to mean legal surrogate mother, in accordance with what has become the ordinary usage of the term. $A$ "surrogate mother" is, of course, the child's biological mother, plain and simple. The term "surrogate" is used because a biological mother who agrees to carry her child for another who ultimately will have legal rights in the child, is acting in the place of that other.

145. If the mother is married, as is customary, see O'Brien, Commercial Conceptions: A Breeding Ground for Surrogacy, 65 N.C.L. REv. 127, 132 n.35 (1986); Parker, Motivation of Surrogale Mothers: Initial Findings, 140 AM. J. Psychiatry 117 (1983), her husband could be designated the second parent. One little explored legal issue in surrogacy arrangements is the conflict that may arise between paternity statutes which, in most states, allow a biological father to rebut any presumption of legitimacy, see Unif. Parentage Act $\S 4$ (b), 9B U.L.A. 287 (1987), and artificial insemination statutes which render the mother's consenting husband the legal father, see Unif. Parentage Act $\S 5,9 B$ U.L.A. 301 (1987). See Bartlett, Courts Not Bound by Parental Agreements, 119 N.J.L.J. Feb 20, 1987, at 27 n.2, col.3; Taylor, Conceiving for Cash; Is It Legal?: A Survey of the Laws Applicable to Surrogate Motherhood. 4 N.Y.L. Sch. HUM. RTS. ANN. 413, 431 \& en 32 (1987). The issue is also raised, but not resolved in Sherwyn \& Handel v. Department of Social Servs., 173 Cal. App. 3d 58, 218 Cal. Rptr. 778 (1985) (dismissing for lack of standing attorneys' challenge to county interpretation of California law that biological father in surrogacy arrangement is not child's father). 
motherhood on the one hand, the powerful drive for reproduction and the value of keeping one's word on the other. This section focuses on a question that may have important consequences for our understanding of parenthood: Whether courts should enforce these agreements through specific performance. ${ }^{148}$

\section{A. The Legal Background}

In the absence of specific legislation covering surrogacy arrangements, ${ }^{147}$ a variety of state statutes may be considered applicable to the specific performance claim. Virtually every state has legislation making the payment of money for a child a crime. ${ }^{148}$ Such legislation, under conventional contract analysis, might render surrogacy contracts illegal and thus unenforceable. ${ }^{149}$

146. This article addresses only the conflict that arises when a party seeks to breach a surrogacy contract at the birth of the child. Numerous other legal issues that can arise under surrogacy agreements are beyond the coverage of this piece. For a more comprehensive description of some of these issues, see Note, Developing a Concept of the Modern "Family": A Proposed Uniform Surrogale Parenthood Act, 73 Geo. L.J. 1283 (1985) [hereinafter, Note, Developing a Concept]; Note, Surrogate Motherhood: Contractual Issues and Remedies under Legislative Proposals, 23 WASHBURN L.J. 601 (1984); Comment, Artificial Insemination and Surrogate Motherhood-A Nursery Full of Unresolved Questions, 17 WILLAMETTE L. REv. 913 (1981).

147. Despite the extensive legislative activity which the surrogate parenting issue has produced, see Surrogate Parenthood: A Legislative Update, 13 Fam. L. Rep. (BNA) 1442 (July 14, 1987) (describing 64 different bills introduced on subject from January to June, 1987), only a few states have enacted laws affecting the legality or enforceability of surrogate parent contracts. Florida and Michigan have prohibited contracts involving the payment of money in connection with a surrogacy arrangement. See Act effective July 1, 1988, ch. 88-143, 1988 Fla. Laws 477 (West); Mich. Comp, LAws $\$ \S 722.581-.722,863$ (1988). State legislatures in Indiana and Louisiana have declared surrogate parenting contracts to be void and unenforceable. See IND. CODE ANN. \$ 31-8-2-2 (Burns Supp. 1988); LA. Rev. Stat. ANN. 9:2713 (Supp. 1983). Only Arkansas and Nevada appear to allow judicial enforcement of surrogacy contracts. See ARK. STAT. ANN. § 9-10-201(c)(1) (1987) (in case of surrogate mother giving birth, child shall be that of "woman intended to be mother"); NEv. REV. STAT. ANN. § 127.287(5) (1988) (anti-baby-selling statute not applicable if woman enters into "lawful contract to act as surrogate").

148. Picrce, Survey of State Activity Regarding Surrogate Motherhood, 11 FAM. L. REP. (BNA) 3001, 3001 (Jan. 29, 1985); see also Katz, Surrogate Motherhood and the Baby-selling Laws, 20 Colum. J.L. \& Soc. Probs. 1, 8 n.34 (1986) (listing 24 statutes prohibiting baby-brokering activities.

149. See Franklin v. Biggs, 14 Or. App. 450, 461-62, 513 P.2d 1216, 1221 (1973) (invalidating adoption based on agreement and $\$ 200$ payment); see also Doe v. Kelley, 106 Mich. App. 169, 173 . 74, 307 N.W. 2 d 438, 440-41 (1981) (declaratory judgment upholding constitutionality of antibabyselling statute in surrogacy context). Even agreements for adoption without the payment of money are invalid. See In Re Rhea, 207 Kan. 610, 612, 485 P.2d 1382, 1384 (1971) (pre-birth agreement by mother allowing her sister to have custody of child not enforceable).

One line of cases has upheld some agreements between family members providing for payment to mothers who relinquish their children for adoption, where courts have been satisfied that the agreements serve the best interests of the children. See, e.g., Reimche v. First Natl Bank of Nevada, 512 F.2d 187 (9th Cir. 1975) (contract between parents of illegitimate child, under which father was to provide for mother in will in exchange for her consent to his adoption of child, held enforceable since adoption was in best interest of child and monetary gain was not prime motivating factor on mother's part); In re Shirk's Estate, 186 Kan. 311, 350 P.2d 1 (1960) (agreement by mother to consent to adoption of child by child's grandmother in exchange for one-third interest in grandmother's estate, upheld as being in best interests of child); Clark v. Clark, $122 \mathrm{Md}$. 114, 89 A. 405 (1913) (agreement providing for payment for adoption in family situation where child's best interests were served by agreement held enforceable). To the extent that these cases depend upon a court's finding that the 
Other state statutes impose procedures and requirements that must be satisfied before an adoption can take place. Some require an adoption to be arranged through a state agency or an agency that has been licensed and approved by the state. ${ }^{150}$ Still others allow a mother some amount of time (either a specific or "reasonable" period) to revoke her relinquishment of her child for adoption, ${ }^{181}$ a waiting period not provided for in most surrogacy contracts. A number of statutes specifically prohibit or invalidate parental consent to adoption before the child is born. ${ }^{152}$ These

agreement serves the child's best interests, they do not stand for the enforceability of certain kinds of adoption contracts, but rather only for the proposition that the contract will not preclude a court from deciding a custody case in the best interests of the child.

Two weaker arguments under conventional contract law analysis could also be made against requiring specific performance of surrogacy contracts. First, to the extent that the contract is a services contract rather than a contract for the sale of goods (see infra text accompanying notes 165-76), specific performance would be an inappropriate remedy. See O'Brien, supra note 145, at 150-51 (discussing principle in surrogacy context); see also A. FARNSWORTH, CoNTRACTs \$12.7, 835-36 (1982) (same in general context); Restatement (Second) of Contracts $\$ 367$ (1) (1981) ("promise to render personal service will not be specifically enforced"). At the point when the pregnancy and delivery are complete and all that remains is the obligation to change legal status, it could be argued that specific performance is also unavailable because an agreement in the context of an intimate family relationship, like promises to marry, cannot be specifically enforced. See Farnsworth, Legal Remedies for Breach of Contract, 70 Colum. L. Rev. 1145, 1150-52 (1970); O'Brien, supra note 145, at 150. Susan Wolf explains how the premises of each of the arguments are inapplicable in the surrogacy context. Wolf, Enforcing Surrogate Mother Agreements: The Trouble with Specific Performance, 4 N.Y.L. SCH. HUM. RTS. ANN. 375, 391-93 (1987).

150. See, e.g., Ala. Code § 26-10-2 (1986); Ariz. Rev. Stat. AnN. § 8-105 (Supp. 1987); Cal. Civ. Code $\S 224 m$ (West 1982); Conn. Gen. Stat. AnN. $\S 17-49$ z (1988); Del. Code AnN. tit. 13, § 904 (Supp. 1986).

Several states make exceptions from these procedures for blood relatives and stepparents. See, e.g., Conn. Gen. Stat. Ann. § 45-63(a)(3) (1988); Del. Code Ann. tit. 13 § 904 (Supp. 1986); FiA. Stat. ANN. § 63.212(1)(a) (West Supp. 1987); Mass. Gen. Laws ANN. ch. 28A, § 11 (West 1981); Minn. Stat. Ann. \$ 259.22(2)(c) (West 1982 \& Supp. 1988); Mont. Code AnN. \$ 40-8-108 \& 109 (1987); N.M. Stat. ANN. § 40-7-34(A)(3) (1986); N.J. STat. ANN. § 9:3-39 (West Supp. 1987).

151. See, e.g., MD. Fam. Law Code ANN. § 5-311(c)(1) (Supp. 1987) (parent may revoke consent up to 90 days or until final decree of adoption, whichever comes first); MiNN. STAT. ANN. $\S$ 259.24(6a) (West Supp. 1988) (parent's consent may be withdrawn for any reason within 10 working days); WASH. Rev. CODE ANN. \$ 26.33.160(2) (Supp. 1988) (consent revocable until court approves adoption); W. VA. CODE $\S 48-4-5$ (b) (1986) (consent revocable within 10 days of execution if formal requirements for parental consent or relinquishment of legal custody not met); see also New York ex rel. Louisa v. Faelia, 37 A.D.2d 598, 322 N.Y.S.2d 831 (1971) (consent to adoption effectively revoked by request for baby's return less than 30 days after surrender); In re Adoption of R.W.B., 485 Pa. 168, 172 n.2, 401 A.2d 347, 349 n.2 (1979) (natural parent may revoke consent at any time until adoption ordered).

152. See, e.g., Alaska Stat. § 25.23.060(a) (1987); ARk. Code. AnN. § 9-9-208(a) (1987); Fla. Stat. AnN. § 63.082(4) (1984); Ga. Code AnN. § 19-8-4 (Cum. Supp. 1988); Ind. Code AnN. $\$$ 31-3-1-6(b) (Burns 1987 \& Supp. 1988); Mo. ANN. STat. \$ 453.030(6) (Vernon 1986); N.D. CENT. CODE $\$ 14-15-07$ (1981). Many states specify a time after the birth of the child before which parental consent to relinquish the child for adoption will not be effective. See, e.g., ARIz. Rev. STAT. ANN. 8107(B) (Supp. 1987) (72 hours); Ill. REv. STAT. ch. 40 II 1511 (1980) (72 hours); Ky. REv. StAT. ANN. § 199-500(5) (Michie/Bobbs-Merrill 1982 \& Supp. 1986) (fifth day); LA. Rev. Stat. AnN. $\S$ 9:422.7(A) (West Supp. 1988) (fifth day); Mass. Gen. LAws ANN. ch. 210, $\$ 2$ (West 1988) (fourth day); Miss. Code AnN. § 93-17-5 (1972) (three days); Nev. Rev. Stat. ANN. \$ 127.070(1) (Supp. 1988) (72 hours); N.H. Rev. STAT. ANN. § 170-B:7 (Supp. 1987) (72 hours); N.M. Stat. ANN. $\S$ 40-7-38(B) (1986) (72 hours); OHIo Rev. Code ANN. § 3107.08(A) (Anderson 1980) (72 hours); 23 Pa. Cons. Stat. AnN. \$2711(c) (Purdon Supp. 1988) (72 hours); VA. Code ANn. \$ 63.1-225(A) (1987) (10 days); see also People ex rel. Anonymous v. Anonymous, 530 N.Y.S.2d 613 (A.D. 1988) (pre-birth consent to adoption voidable). Texas allows a suit to be filed for the involuntary termina- 
statutes, too, arguably render surrogacy arrangements illegal..$^{\mathbf{1 5 3}}$

Finally, state statutes limit the grounds upon which parental rights may be involuntarily terminated, usually to circumstances involving parental unfitness, neglect, abandonment, or failure to support. ${ }^{154}$ Courts have recognized that the right of parents to continued custody of their children has constitutional dimensions. ${ }^{158}$ Unless it is determined that these statutory and constitutional protections can be waived before the birth of a child, ${ }^{158}$ the specific enforcement of surrogacy contracts would violate them as well.

\section{B. Rights Claims}

\section{Constitutional/Moral Rights Claims}

When a biological mother reneges on her contractual agreement to give up the child to the father and his wife under a surrogacy arrangement, the constitutional arguments on both sides follow a familiar pattern. On behalf of couples seeking enforcement of surrogate parent contracts, it is argued that individuals have a constitutional right to procreate. Since individuals are constitutionally protected in reproducing coitally, the argument goes, they also have a constitutional right to reproduce noncoitally. ${ }^{157}$ The equal protection clause provides an alternative constitu-

tion of parental rights before a child is born, but no hearing may be held on the petition until the child is at least five days old. Tex. FAM. Code ANN. § 15.021(a) \& (b) (Vernon Supp. 1988). Similarly, the state of Washington allows a petition for relinquishment to be filed before the child's birth, WASH. REV. CODE $\$ 2633.080$ (3) (Supp. 1988), but a hearing may not be held on the petition sooner than 48 hours after the child's birth, 26.33.090(1). For a short while, one state, Wyoming, specifically allowed pre-birth relinquishment of a child for adoption. See Wyo. STAT. \$1-22-109(c) \& (e) (Supp. 1986), interpreted in Matter of Adoption of B.G.D., 719 P.2d 1373, 1375-76 (Wyo. 1986). The statute has since been amended to allow relinquishment only after the birth of the child, as in other states. Wyo. STAT. § 1-22-109(c) (1988).

153. See infra text accompanying notes $164-176$.

154. See, e.g., Ala. Code $\S \S 26-18-7$ (1986); ConN. Gen. Stat. AnN. §§ 45-61c to 45-61h (West 1981 \& Supp. 1988); Del. Code ANN. tit. 13, § 1103 (1981); Mo. ANN. STat. $\$ 211.447$ (Vernon Supp. 1988); TeX. FAM. Code ANN. \$§ 15.02 (Vernon 1986):

155. See, e.g., Santosky v. Kramer, 455 U.S. 745 (1982) (parents entitled to clear and convincing standard of proof in termination of parental rights hearing).

156. Pre-birth waiver of the parents' constitutional rights raises the same policy issues as the alteration by contract of the statutory protections of parents in the adoption process. See infra text accompanying notes 164-176.

157. See, e.g., Andrews, The Legal Status of the Embryo, 32 LOY. L. REv. 357, 359-61 (1986); Graham, Surrogate Gestation and the Protection of Choice, 22 SANTA Glara L. Rev. 291 (1982); Keane, Legal Problems of Surrogate Motherhood, 1980 S. ILL. U.L.J. 147, 165; Robertson, Embryos, Families and Procreative Liberty: The Legal Structure of the New Reproduction, 59 S. CAL. L. REv. 939, 958-64, 1040 (1986); Note, Developing a Concept, supra note 146, at 1295-98; Comment, Prohibiting Payments to Surrogate Mothers: Love's Labor Lost and the Constitutional Right of Privacy, 20 J. Marshall L. Rev. 715, 729-30 (1987); Comment, Surrogate Mother Agreements: Contemporary Legal Aspects of a Biblical Notion, 16 U. RICH. L. REv. 467, 479-82 (1982) [hereinafter Comment, Surrogate Mother Agreements]; Note, The Rights of the Biological Father: From Adoption and Custody to Surrogate Motherhood, 12 VT. L. REv. 87, 108-11 (1987) (hereinafter Note, The Rights of the Biological Father]; see also In re Baby M., 217 N.J. Super. 313, 386, 525 A.2d 1128, 1164 (Ch. Div. 1987), aff'd in part, rev'd in part, 109 N.J. 396, 537 A.2d 1227 (1988). 
tional argument. If men are allowed to sell sperm, on similar reasoning women must also be allowed to sell their reproductive services. ${ }^{168}$

In opposition to these claims, women make two related arguments. The first links entitlement to the child to the woman's role as biological mother: By the time the child is born, mothers have invested nine months of personal risk and sacrifice, discomfort and pain, all of which outweigh the trivial burden to fathers of donating sperm for the purpose of artificial insemination and having their expectations frustrated. ${ }^{139}$ The second argument draws the familiar analogy between abortion and custody: Because a woman has a constitutional right to abort the fetus during pregnancy (regardless of the stake the father may have in seeing the pregnancy continue to term), she also has preemptive rights to the child at birth. ${ }^{180}$

All of these arguments are deeply rooted in an exchange view of parenthood. Women's claims to parental rights based upon their investment in carrying and bearing a child, and the arguments of biological fathers based upon surrogate mother contracts, justify entitlements according to deeds done (pregnancy and childbirth), or commitments made (the contract). The hardships experienced by the mother in pregnancy and childbirth are seen not as an inevitable and defining element of parenthood, but (by the woman) as a detriment suffered that entitles the mother to a right or (by the man) as an item of contractual exchange. Likewise, the obligation assumed by the father to assume care and custody of the child is seen not as a contingent aspect of a formative personal relationship but as the consideration entitling the father to enforce the mother's reciprocal promise to give up the child. The claims of both mothers and fathers, in sum, focus on actions of the adult that are asserted to give rise to mature rights, based upon principles of fairness and equity between those adults.

The remaining arguments on behalf of both mothers and fathers rely

158. The Baby $M$. court put it this way: "If a man may offer the means for procreation then a woman must equally be allowed to do so." 217 N.J. Super. at 388,525 A.2d at 1165 . See also Coleman, Surrogate Motherhood: Analysis of the Problems and Suggestions for Solutions, 50 TENN. L. REv. 71, 81-82 (1982); Keane, supra note 157, at 153; Lorio, Alternative Means of Reproduction: Virgin Territory for Legislation, 44 LA. L. REv. 1641, 1653 (1984); Note, Developing a Concept, supra note 146, at 1293-94; Comment, Baby-Sitting Consideration: Surrogate Mother's Right to "Rent Her Womb" for a Fee, 18 GoNz. L. REv. 539 (1982-83); Comment, Parenthood by Proxy: Legal Implications of Surrogate Birth, 67 lowA L. REv. 385, 386 (1982); Comment, Surrogate Motherhood: The Need for Social Acceptance, 13 OHio N.U.L. REv. 517, 524 \& n.62 (1986).

159. See Annas, Redefining Parenthood and Protecting Embryos: Why We Need New Laws, 14 The Hastings Center ReP. 50, 51 (1984) (mother has contributed more of herself and thus has greater investment in child); Eisenberg, Surrogate-Mother Contracts, 20 The Boal.t Hall. Trans. 10 (Fall/Winter 1987) (mother's bond to newborn infant stronger than those of father "who has not participated, even in a companionate way, in the pregnancy"); Stanworth, The Deconstruction of Motherhood, in RePRoductive Technologies, supra note 46, at 10, 22 (women's claims to children based upon commitment involved in pregnancy and birthing, and fact that mothers assume dayto-day responsibility for care of children); Note, The Rights of the Biological Father, supra note 157, at $108-11$.

160. O'Brien, supra note 145 , at 151 . 
upon precedent that is entirely inconclusive as to the question it purports to resolve. The claim to custody rights made by surrogate mothers based upon the woman's privacy right to choose abortion overlooks the weakening of the mother's interests as her fetus develops. ${ }^{161}$ As to her rights against the father, constitutional precedent outside the limited context of abortion establishes the rights of parents, not just women, to their children. ${ }^{162}$ Hence the argument proves, and ignores, too much.

So also the father's right to procreate and his right to buy the reproductive services of a woman are inadequate to justify his claim. There may be, indeed, a "right" to non-coital reproduction. But this right, like the other constitutional claims made in this context, has limited content, ${ }^{163}$ and little usefulness in settling custody disputes between two biological parents.

\section{Statutory Rights Claims}

The debate over surrogacy also focuses on the applicability of antibaby-selling, adoption, and termination of parental rights statutes. ${ }^{164} \mathrm{Ar}-$ guments on behalf of fathers seeking contract enforcement distinguish between the performance of services entailed in surrogacy agreements and baby-selling, which is prohibited under adoption statutes. ${ }^{105}$ This argument has had some success in the courts. ${ }^{188}$ It is, however, a formalistic argument that ignores the underlying purposes of adoption regulations. Statutes prohibiting the exchange of money for adoption are meant to avoid the injury to personhood that would accompany the placement of specific monetary value on individuals. ${ }^{187}$ The objective of a surrogate mother contract is to transfer parental rights from the mother to the biological father and his wife. Surrogate contracts generally fail to make explicit the intention that the wife of the biological father will ultimately adopt the child, in order to promote the fiction that the transaction is limited to dealings between biological parents both of whom already have

161. See Roe v. Wade, 410 U.S. 113 (1973).

162. See supra note 77 and accompanying text.

163. See O'Brien, supra note 145, at 140; Stark, Constitutional Analysis of the Baby M. Decision, 11 HARv. WOMEN's L.J. 19, 23-33 (1988).

164. See supra notes $148-156$ and accompanying text.

165. See, e.g., Coleman, supra note 158, at 108-17; Katz, supra note 148, at 21, 25; Keane, supra note 157, at 154-59; Note, Developing a Concept, supra note 146, at 1289-92; Note, Litigation, Legislation, and Limelight: Obstacles to Commercial Surrogate Mother Arrangements, 72 Iowa L. Rev. 415. 422-27 (1987); Comment, Surrogate Mother Agreements, supra note 157, at 476-79; Note, Legal Recognition of Surrogate Gestation, 7 Women's Rts. L. Rep. 107 (1982).

166. See Surrogate Parenting Assocs. v. Commonwealth ex rel. Armstrong, 704 S.W.2d 209 (Ky. 1986) (distinguishing surrogate parenting arrangements from buying and selling of babies); In re Baby M., 217 N.J. Super. 313, 525 A.2d 1128 (Ch. Div. 1987), affd in part, rev'd in part, 109 N.J. 396, 537 A.2d 1227 (1988) (adoption statutes not applicable to surrogacy arrangements); In re Adoption of Baby Girl L.J., 132 Misc. 2d 972, 505 N.Y.S.2d 813 (1986) (\$10,000 fee in surrogacy arrangement does not violate New York statute prohibiting compensation in connection with adoption).

167. See In re Baby M., 109 N.J. at 423-25, 537 A.2d at 1241. 
rights to the child. ${ }^{168}$ But at the heart of most arrangements, as at least one court has recognized, is the expectation that the child's biological mother will consent, for money, to the biological father's wife taking her place as the child's mother. ${ }^{109}$

More fundamentally, who the parties to a surrogate contract are does not change the commercial nature of the transaction. The crictical fact is that surrogacy arrangements, however dressed up, constitute bargain and exchange over the incidents of parenthood. Even the father, whose biological connection to the child is seen as the reason for differentiating adoption from surrogacy, ${ }^{170}$ pays money for the purpose of obtaining a package of rights to a child-a package to which he would not otherwise be fully entitled. ${ }^{171}$

The distinctions between surrogacy and adoption likewise have little relevance to the state policies served by rules that do not allow a parent to relinquish parental rights until the birth (or some specific length of time after the birth) of the child. ${ }^{172}$ States are concerned that parents who surrender their children for adoption do so only after making careful, wellconsidered decisions. ${ }^{173}$ Some courts and commentators have argued that surrogate mothers do not make hurried agreements under emotional and financially-strained circumstances and are thus not vulnerable to pressure and exploitation. ${ }^{174}$ This argument, however, makes too much of the difference in timing, and too little of the economic pressures presumably kept under control by statutes prohibiting the payment of money for babies. ${ }^{175}$ The critical fact is that surrogacy arrangements allow women (and men)

168. See Clark, New Wine in Old Skins: Using Paternity-Suit Settlements to Facilitate Surrogate Motherhood, 25 J. FAM. LAw 483, 505-07 (1986-87).

169. The New Jersey Supreme Court recognized the difficulties with the goods/services distinction in rejecting the analysis of the trial court in In re Baby $M$. that adoption laws did not apply to surrogacy arrangements. See In re Baby M., 109 N.J. at 423-25, 537 A.2d at 1240-41; see also Kentucky ex rel. Armstrong v. Surrogate Parenting Assocs. 11 Fam. L. Rep. (BNA) 1359 (Ky. Ct. App. 1985) (Kentucky's prohibition of baby-selling applies to surrogate parent contracts), rev'd, 704 S.W.2d 209 (Ky. 1986); Miroff v. Surrogate Mother, 13 Fam. L. Rep. (BNA) 1260 (1987) (upholding adoption by father and stepmother, but ruling surrogate contract violative of public policy prohibiting baby-selling and thus unenforceable).

170. Surrogate Parenting Assocs., 704 S.W.2d 209 (Ky. 1986); In re Baby M., 217 N.J. Super. $313,372-74,525$ A.2d 1128, 1157-58 (Ch. 1987), affd in part, rev'd in part, 109 N.J. 396, 537 A.2d 1227 (1988); id., 109 N.J. at 434 n.8, 537 A.2d at 1246 n.8.

171. See Capron, Alternative Birth Technologies: Legal Challenges, 20 U.C.D. L. REv. 679, 703 (1987) (drawing comparison to one joint tenant paying other to give up rights in property).

172. See supra notes 151-52.

173. See, e.g., Sees v. Baber, 74 N.J. 201, 377 A.2d 628 (1977).

174. See Surrogate Parenting Assocs., 704 S.W.2d at 211, 212; Note, Developing a Concept, supra note 146, at 1288; Comment, Revocation of Parental Consent to Adoption: Legal Doctrine and Social Policy, 28 U. CHI. L. REv. 564, 570, 571 (1961); Comment, Surrogate Mother Agreements, supra note 157, at 478-79; Note, Moppets on the Market: The Problem of Unregulated Adoptions, 59 YALE L.J. 715, 724-29 (1950). This argument was endorsed by the trial court in In re Baby M., 217 N.J. Super. 313, 372, 525 A.2d 1128, 1157, but was rejected on appeal by the New Jersey Supreme Court, 109 N.J. 396, 437-38, 537 A.2d 1227, 1248 (1988).

175. See supra notes 148-49. 
to view the ability of a woman to bear a child as the source not only of procreation, but of commercial profit as well. ${ }^{178}$

\section{Relationships and Responsibility Within Surrogacy Arrangements}

The debate over surrogacy raises important issues about the source of responsibility within the parent-child relationship. To what extent does responsibility flow from physical or psychological connections, as custody law assumes, and to what extent may it be established from within the private, contractual setting, to which contract law ordinarily applies?

Within custody law, there is a strong ideology that through pregnancy and childbirth an enduring bond develops between mother and child which cannot easily be broken. This mystical bond is perceived of as inevitable and more powerful than any woman can realize in advance. ${ }^{177}$ State statutes that regulate adoption, particularly those statutes limiting prebirth adoption agreements, reflect this ideology. Insofar as the ideology designates women as the natural rearers of children, it has been used to limit women's options outside the home, especially in the workplace, and thus has not been entirely favorable to women. ${ }^{178}$ But as a model for how we might want parents to feel about their children, it seems a constructive starting point-certainly a better one than the model of sperm donation to which society, through its artificial insemination statutes, gives an entirely functional, non-relational meaning.

Subsuming custody questions into contract law principles in surrogacy contexts reconstructs the ideology of motherhood by dissociating gestation and relationship. Whether this reconstruction is a desirable one is a question not easily answered. The effects of the reconstruction vary for each mother-child-father triad, and desirable effects often have undesirable counterparts. For example, surrogacy reinforces the bond of the biological father and child, enhancing the ideal that fathers are responsible for their children. At the same time, however, it presupposes that the biological mother-child bond is easily severed, that pregnancy and childbirth is a process which does not necessarily entail enduring human emotion and permanent connectedness, that women can have children and give them up

176. See Surrogate Parenting Assocs., 704 S.W.2d at 216 (Wintersheimer, J., dissenting); see also infra note 179.

177. For one statement of this ideology, see Lacey, supra note 63, at 317 ("It is impossible for a woman to predict in advance how she will feel during pregnancy. As she carries a child and begins to feel it move inside her, her emotional attachment to the child may grow beyond her original expectations.").

178. See C. Smart, supra note 46, at 177-80, 208-13; Williams, Equality's Riddle: Pregnancy and the Equal Treatment/Special Treatment Debate, 13 N.Y.U. REv. L. \& Soc. Change 325, 352-53 (1984-85). For a revicw of feminist views on the oppressive dimensions of women's role as reproducers, see Rose \& Hanmer, Women's Liberation, Reproduction, and the Technological Fix, in Sexual. Divisions and Society: Process and Change 199-200 (D. Barker \& S. Allen eds. 1976). 
if the price is right, ${ }^{179}$ and that women who make such agreements and change their minds are acting improperly, even pathologically. ${ }^{180}$

Surrogacy's effect on the ideology of adoption is also mixed and contradictory. On the one hand, by recognizing the adoptive mother's connection to the child, surrogacy reinforces non-biological parenthood, rendering adoption a co-equal rather than a second-class alternative to biological parenthood. ${ }^{181}$ At the same time, enforcing surrogacy contracts approves the conflicting notion that having a child "of one's own" is very important, especially for a man. ${ }^{182}$

Finally, surrogacy arrangements may help to dilute the stereotype of the woman in the nuclear family whose role is confined to that of mother and homemaker: "The bond between mother and child is demystified, made clear, intelligible, scientific - and also provisional, revocable and of no more than contractual force." ${ }^{\text {"18s }}$ At the same time that surrogacy frees women from some oppressive stereotypes, however, it seems slyly to recreate them. Surrogacy strengthens the notion that infertility and childlessness is "bad."184 It also depends upon a continued underclass of women-the surrogates-who will continue to be bound to their role as babymakers. ${ }^{185}$

179. Margaret Radin, in what is perhaps the most comprehensive treatment of the commodification issue raised by surrogacy, concludes that surrogate arrangements, or at least the exchange of money pursuant to surrogate arrangements, should be banned. Radin, Market Inalienability, 100 HaRv. L. REv. 1849, 1928-36 (1987). Many of her concerns, like mine, are ideological. Surrogacy, she argues, "expresses an inferior conception of human flourishing," commodifying the reproductive capacity of women and children, and potentially, because of the rhetoric necessary to justify surrogacy, "leav[ing] us all inferior human beings." Id. at 1930. This reasoning was adopted recently by a Michigan trial court, which found surrogate parenthood contracts unenforceable on the grounds that surrogacy "denigrates human dignity." Yates v. Keane, 14 Fam. L. Rep. (BNA) 1160 (Mich. Cir. Ct. 1987); see also O'Brien, supra note 145, at 140,142-47. Radin explores in some detail the suggestion that the use of "services" rhetoric might avoid the injury to notions of personhood that marketing babies would otherwise cause. Radin, supra at 1931. The idea is that if we speak of surrogacy as the sale of services rather than the sale of babies, there will be less negative spillover (or, in her terms, a reduced "domino effect") from allowing the practice. Radin rejects this analysis as "implausible," given society's unwillingness to justify ordinary adoption-for-money in this way. Id. at 1926, 1930.

180. See In re Baby M., 217 N.J. Super. at 392-94, 525 A.2d at 1167-68. The literature designed to counsel surrogate mothers and their doctors about how to suppress maternal instincts already has become quite extensive (and, to my mind, frightening). The leading "consumer's guide" to surrogacy, for example, gives this advice: "The surrogate must begin to erect an emotional barrier ... so that she experiences the child not as hers but as the child of the couple." L. ANDREWS, NEw Conceptions 221 (1984); see also Katz, supra note 165, at 21. It is reported generally that in order to be chosen as a surrogate mother, the woman must demonstrate both "a strong wish for children," and the ability "to abandon this wish." Zipper \& Sevenhuijsen, supra note 46, at 131-31.

181. Radin, supra note 179, at 1931; N. Taub, Concepts of Motherhood and Reproductive Choice: Feminist Tensions 9 (1988) (unpublished manuscript).

182. Radin, supra note 179 , at 1929-30. This notion feeds the further understanding that the important genetic line is the male line, and that women are fungible in helping to perpetuate it. Id. at 1930.

183. Scruton, Ignore the Body, Lose Your Soul, The Times (London), Feb. 5, 1985, at 10, col. 5.

184. Morgan, Making Motherhood Male: Surrogacy and the Moral Economy of Women, 12 J.L. \& Soc. 219, 232 (1985).

185. Professor Radin spells out the particular ways in which surrogacy reinforces oppressive gender roles creating the "ironic" self-deception for poor women whose economic options are enhanced by surrogacy. Radin, supra note 179 , at 1930-31. 
Given the mixed ideological effects of surrogacy, and keeping in mind that responsibility requires both strong affirmation and sufficient latitude for parents freely to choose to act responsibly, it would seem unwise either to criminalize surrogacy contracts or to allow specific enforcement of them. ${ }^{188}$ Declining the use of courts to enforce private surrogacy arrangements, even while allowing parties to make them, would retain, without coercing, the assumption (or ideology) of current law-that, ordinarily, parents will not give up their children. It would affirm that wanting to keep one's children, even where one has previously agreed otherwise, is not pathological or wrong, but rather understandable and defensible. It would also reject the meaning of pregnancy as a calculated choice between bearing a child with whom the mother will have a relationship (without pay) or bearing a child for another (for pay). Such a meaning focuses on the needs and interests of individual adults, bargaining for their own advantage, rather than on the general norm that one's pregnancy is the beginning of an ongoing, responsible parent-child relationship.

Declining to enforce surrogacy arrangements would also disaffirm the notion of "convenient" childbearing. Some couples may seek surrogacy arrangements not because they are infertile but because they find pregnancy and childbirth undesirable. The reasons may range from wishing not to risk passing on genetic defects to desiring to avoid the health risks, pain, physical distortion, or annoyance of pregnancy. ${ }^{187}$ As a wider range of reasons becomes acceptable, the danger to be avoided is that parenthood will come to be understood as a recreational activity from which adults can experience pleasure dissociated from inconvenience.

Declining to enforce surrogacy contracts, finally, rejects the notion of reciprocity of obligation-that because the father has bound himself to a contract, the mother also should be bound. ${ }^{188} \mathrm{~A}$ non-exchange, responsi-

186. A comparable position was taken by the Supreme Court of Kentucky. In Surrogate Parenting Assocs. v. Commonwealth ex rel. Armstrong, 704 S.W.2d 209 (Ky. 1986), the court purported to validate surrogate parenting procedures, but found them subject to Kentucky statutes giving parents five days following the birth of the child to revoke a relinquishment for adoption. Id. at 212-13. While this statutory construction means that contracts will not be found illegal despite their attempt to limit prematurely the rights of parties, as a practical matter they cannot become enforceable until the statutory waiting period has expired. See also Garrison, Surrogate Parenting: What Should Legislatures Do?, 22 FAM. L.Q. 149 (1988) (arguing that existing law, which she interprets as making surrogacy contracts neither criminal nor enforceable, is adequate).

187. In Baby $M$., for example, the father's wife who intended to adopt the child apparently had exaggerated fears of the effect of pregnancy on her multiple sclerosis. In re Baby M., 217 N.J. Super. at 379-80, $525 \mathrm{~A} .2 \mathrm{~d}$ at 1161-62. The reasons for a surrogacy arrangement may be quite relevant to society's tolerance of it. Sixty-three percent of those poiled by Newsweek approved of surrogacy arrangements where a wife was unable to bear a child (33\% disapproved), $54 \%$ approved where pregnancy was a significant risk to the wife's health (39\% disapproved), and $14 \%$ approved where the wife was afraid to bear a child (81\% disapproved). Kantrowitz, McKillop, Joseph, Gordon \& Turque, Who Keeps 'Baby M'?, NewSWEek, Jan. 19, 1987, at 48.

188. This argument is problematic even on its own terms. One wonders whether a man would, or should, be compelled specifically to perform under a contract to sell his sperm if he changes his mind after the agreement is made. I decline here to discuss such questions because my objection is to the use of the reciprocity principle, however it may be applied, in child custody disputes. 
bility-based construction of parenthood lives comfortably with rules that may compel responsibility from a parent even though that parent would not be able to compel recognition of his or her own rights under all circumstances. ${ }^{189}$ Likewise, it downplays concerns of fairness to either parent which might otherwise interfere with the resolution of custody disputes based on the primacy of relationship over individual interest.

As we have seen, custody law applicable to disputes between unmarried parents tends to favor a child's mother. ${ }^{190}$ When both parents feel strong instincts toward their children, it is unfortunate that a continuing, meaningful relationship between the child and both parents is impractical. When it is, a hard choice must be made, and should be made not on the basis of fairness to either parent, but according to rules that affirm responsible parent-child relationships, giving priority to those that have already been formed. In many cases, the biological father will be required to accept the disappointment of his expectations of parenthood, in the face of the existence of a parent-child relationship that, through the vagaries of biology, will give an initial advantage to the mother. ${ }^{101}$ In some cases, the father may be able to demonstrate a stronger commitment or relationship to the child. ${ }^{192}$ But it is this demonstration of responsibility and commitment to the quality of the relationship, not fairness and equality for the parents, that should make the difference.

Adults can be disappointed in many ways when they set out to have children, often for reasons totally beyond their control. Parents who attempt surrogacy arrangements are likely to have already suffered a series

189. These rules could compel a surrogate mother to accept responsibility for a child she does not want, such as when the father dies or becomes unable to care for the child, as well as a father, who might change his mind about following through with a surrogacy arrangement. In both cases, the involvement of the parent in the surrogacy arrangement creates obligations which, though unintended, the parent is best situated to assume. The biological father in a surrogacy arrangement initiates an arrangement for his own benefit, leading to the birth of a child for whom someone must be responsible. The surrogate mother also presumably chose to participate in the arrangement, and if it unravels, our need to assign responsibility to a parent may make it appropriate to consider her, as well as the father, a likely prospect. In any event, it should be noted that in these circumstances, the unwilling parent would not necessarily be coerced into taking custody of the child, any more than the state now coerces biological parents into assuming custody of their children. The obligations of the unwilling parents in a surrogacy arrangement and the stigma of not accepting the children, however, would be no less than what is imposed on other parents.

A rare example of judicial approval of the imposition of an apparently uneven, arguably "unfair," set of rights and burdens upon parents in the service of the relationship needs of the child is provided in Michael U. v. Jamie B., 39 Cal.3d 787, 792, 705 P.2d 362, 365, 218 Cal. Rptr. 39, 42 (1985) (while both natural father and presumed father have same burdens of support for child and liability for expenses of mother's pregnancy and confinement, natural father may not have initial custodial or veto rights equal to those of presumed father).

190. See supra note 53. The New Jersey Supreme Court in Baby $M$. stated that where father and mother are separated and disagree about custody, the child should be taken from its mother pendente lite "only in the most unusual case." In re Baby M., 109 N.J. at 462, 537 A.2d at 1261.

191. See supra text accompanying notes 126-130.

192. Where the father has been given custody of the child before the mother changes her mind, his ability to demonstrate this commitment and relationship will be greatly enhanced. See Clark, supra note 168 , at 492 . 
of disappointments in attempting to conceive, and perhaps also to adopt. ${ }^{193}$ But their disappointment, their good works, their noble efforts to overcome the disadvantages they may face in achieving parenthood, and even the agreements they may be able to make before the child's conception, cannot, without more, justify their claims. Relationships are the heart of our social and individual beings. They should be viewed not as earned, or subject to barter or exchange, but as opportunities given to us to express who we are.

\section{Conclusion}

\section{A. The "Endless (Ex)change"194}

Changing the way society approaches questions about an adult's status as parent is a long-term project, very long-term. In this article I have identified the extent to which our current legal thinking, shaped by an exchange view of parenthood, causes us to focus on an individual parent's achievement, biological contribution, and "rights," and thereby to conceive of parenthood in individualistic, possessory terms. I have argued that meanings of responsibility provide more appropriate norms for the parentchild relationship, and I have suggested how a society attempting to promote such meanings might approach particular conflicts that arise when adults make conflicting claims of parenthood.

These suggestions come without a detailed set of legislative or judicial proposals. This is in part because I do not wish any such proposals, which would necessarily be contestable, to detract from the case I wish to make for shifting from a regime of individual rights to one of relationship and responsibility. The more fundamental reason, however, is that specific guidelines at this moment might be misleading, implying a finality or surety that is neither possible nor even desirable. To the extent that I have suggested how certain issues might be resolved, these suggestions were simply to illustrate that rules can be designed within a debate that focuses on issues of responsibility and relationship. My principal point is that the debate should center around these issues, rather than build further on the individual rights doctrine to which we have become so accustomed. I have also shown that the outcome of this debate is not necessarily conservative

193. See L. ANDREws, supra note 180, at 1-4, 8-11; O'Brien, supra note 145, at 129; Robertson, supra note 157 , at $1028-29$.

194. The term "endless (ex)change" comes from Barbara Herrnstein Smith, who uses it to describe the operation of value in human life in a way that avoids the traditional, dualistic "double discourse of value" which maintains a sharp distinction and opposition between our economistic, utility-maximizing side, and our humanistic, spiritual side. See B. SmIth, Contingencies of Value: Alternative Perspectives for Critical Theory 125-34, 144-49 (1988). The term seems apt here, not only as a manipulation of the exchange view of parenthood which I wish to change, but as an explanation of the permanent and interactive process of publicly defining and implementing norms such as parental responsibility that engage so many conflicting human urges, tendencies and values. 
in a political sense; ${ }^{105}$ moral discourse is not the exclusive province of the political right and need not lead, inevitably, to the standardization of family structures. Finally, I have suggested that the questions implicated by the parenthood conflicts discussed in this article are fundamental enough to engage us in a long and continuing-indeed endless-conversation, or (ex)change, about defining ourselves as a society. To suggest an endpoint, or anything more than a possible direction for this conversation would be to deny its character and its significance. ${ }^{198}$

There is another problem with specificity. As any new approach becomes reduced to specific rules, those rules become proxies for the original principles sought to be served. Thus, shifts away from rights tend, perhaps inevitably, to collapse back into rights. ${ }^{197}$ For example, if at the birth of the child the mother's experience through pregnancy and childbirth is said to constitute the relationship with the child to which we should attach the most significance for purposes of promoting responsibility, it will be said (and the mother will claim) that the mother of a newborn has a "right" to the child. Indeed, it is the function of rules to encapsulate the objectives they intend to implement. ${ }^{198}$ The collapsing tendency is unavoidable, particularly within a legal system (alternatives to which have not yet been imagined) which sets claimants against each other as legal adversaries and forces those individuals to make claims against each other in terms that establish their entitlement to the "rights" they seek.

But although our system tilts us toward thinking in terms of rights, we should resist. We constantly should be calling up and reevaluating the ultimate objectives we wish our law to serve, rejecting doctrine that forces us to think of and present ourselves in terms that deny who we, at our best moments, want to be. We should, moreover, concentrate more energy on how to improve the meanings the law conveys through its rhetorical activity. ${ }^{190}$ At stake are not merely the results of particular cases, but also our definitions of ourselves.

195. Several commentators seem to conclude that the influence of moral discourse on law and politics is conservative. See, e.g., Hafen, supra note 9, at 550 (arguing for a policy presumption in favor of traditional values); Schneider, Moral Discourse, supra note 9, at 1871-75 (describing "new conservatism" as force that may reinject moral discourse into law).

Suzanna Sherry, like myself, has attempted to reclaim values and virtues rhetoric from the conservative right. See Sherry, supra note 6, at 985-89.

196. See M. Walzer, Interpretation and Social Criticism 49 (1987) (more argument has no end, only temporary stopping points); $c f$. C. MACKINNON, supra note 72, at 45, 77 (one cannot state program for future before we know what women are like when they are not oppressed); Tushnet, Critical Legal Studies: An Introduction to its Origins and Underpinnings, $36 \mathrm{~J}$. LEGAL. EDuc. 505, 515 (1986) (critical project "cannot set forth a permanent program, the realization of which would be the end of politics").

197. Roberto Unger's concept of "destabilization rights" is designed in part as a means of transcending this process in which law reform crystallizes into static rights. Unger, The Critical Legal Studies Movement, 96 HARv. L. Rev. 561, 600, 611-15 (1983). While this concept is not very practical, Unger's analysis is helpful in explaining how rights become static.

198. See Schauer, Rights as Rules, 6 LAw \& PriL. 115 (1987).

199. The standards of Joseph Goldstein, Anna Freud and Albert Solnit for state intervention in 


\section{B. A Feminist Postscript}

If to some my proposals are insufficiently specific, to others they will seem to take an alarming direction. As a feminist, I see trouble on both flanks. From the right is the criticism implied in the response of one of my colleagues: "I get it. The woman always wins." From my left is the charge that the approach I propose is not feminist-that it is not explicitly women-centered and that, by turning us away from women's "rights," it is inadequately attuned to enhancing the power of women.

The complaint that my analysis merely rationalizes standards designed to favor women is a difficult one to refute. I have argued that the parentchild relationship should receive higher status in our law than fairness and individual entitlement based upon principles of reciprocity and exchange. The fact that women by virtue of their biological and current social positioning often have an edge with respect to the parent-child relationship ${ }^{200}$ is unfortunate from the point of view of any androgynous goals we might have. In making my arguments, however, I do not assume the inevitability of the current social order with its advantages for men, or of any other particular order; I argue in favor of one, and invite others to argue theirs. Objections based upon who wins or who loses must be made within the debate over what it is we are trying (and can justify trying) to achieve.

The criticism that my approach is inadequate in advancing the empowerment of women reflects, in large part, a disagreement over tactics and vision. Like other feminists, I object to the genderized hierarchy that oppresses women. But I am not indifferent to the means by which we seek to end that oppression. Rules explicitly designed to allow women to win custody disputes on their own terms for the sake of enhancing the power of women would perpetuate the male norms of power and advantage, while

families and for child placement in divorce, abuse and neglect cases offer a useful model of improved legal rhetoric. See BEFORE THE BEST INTERESTS, supra note 41, at 187-96; BEYOND THE BEST INTERESTS, supra note 12, at 97-101. These standards, applicable to custody disputes between thirdparties and biological parents, use rhetoric that clarifies and reinforces their underlying premises and objectives, and thus serves the law's expressive purposes. Thus, for example, in defining the "least detrimental available alternative" principle governing child placement decisions, the standards state: "The least detrimental available alternative is that child placement and procedure for child placement which maximizes, in accord with the child's sense of time . . . the child's opportunity for being wanted ... and for maintaining on a continuous, unconditional, and permanent basis a relationship with at least one adult who is or will become the child's psychological parent . . . BEYOND THE BEST INTERESTS, supra note 12, at 99 . The relationship between the approach I propose and these standards is discussed supra at text accompanying notes $41-46$ and note 43 .

200. Women will not necessarily have an edge in all conflicts over exclusive status as parents of newborns. For example, where biological parents compete for a child who has a third-party gestational mother, see Robertson, supra note 157, at 1011-12; Comment, Love's Labor Lost: Legal and Ethical Implications in Artificial Human Procreation, 58 U. DET. J. URB. L. 459, 471 (1981), there will be no reason to prefer for custody the mother who contributed her egg over the man who contributed his sperm. Then, in the absence of more meaningful indicia of responsibility, other factors, such as the respective abilities of the adulis to parent, predictability of result, or even, perhaps, the expectations of the parties, must control. See supra text accompanying notes 12-16. 
doing nothing to further a transformation and reordering of values associated with childrearing that is critical to any credible progressive vision of a better world.

More revolutionary goals are needed to transform the terms upon which we relate to one another. Legal standards that elevate relationship and responsibility over individual rights and personal power are examples of such goals. These, and other more humane and cooperative norms, must inform how we address the power issue, for if we set out to acquire power for its own sake-allowing the enhancement of power for women to be our first and last goal-the transformation we have wrought will be of only a very limited sort. ${ }^{201}$

I do not advocate the rejection of power as a norm so that the powerless, especially women, will be more accepting of their powerlessness. I seek, more radically, to promote new standards upon which women and men will relate, elevating other-directed over self-serving values within relationships. Women have so little power now because the activities and characteristics assigned to them have been valued poorly in relation to those assumed by men, and because the differences associated with women have been used to devalue women as individuals. What must change is not only the imbalance of power, but how we value the activities, norms and differences between men and women that have been used to perpetuate gendered hierarchy. Our ultimate goal should be not revenge, but a world in which women and men relate to one another and to their children in improved, more responsible and caring ways.

201. Bartlett, MacKinnon's Feminism: Power on Whose Terms?, 75 CAlif. L. Rev. 1559, 1567-68 (1987). 